\title{
CARTOGRAPHIC IMAGES OF SLOVENIA THROUGH TIME
}

\section{KARTOGRAFSKE UPODOBITVE SLOVENIJE SKOZI CAS \\ Primož Gašperič}

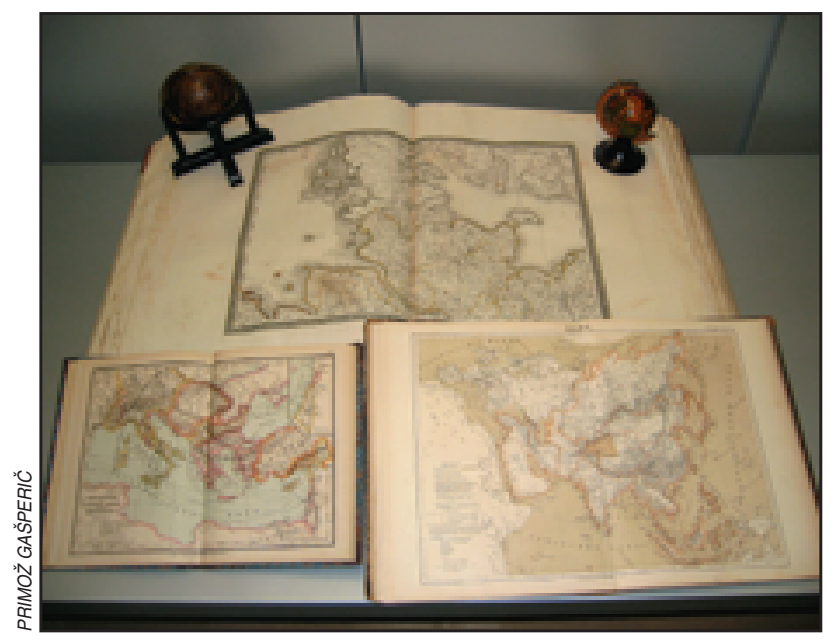

Cartographic material is a part of national cultural heritage.

Kartografsko gradivo je del kulturne dediščine vsakega naroda.

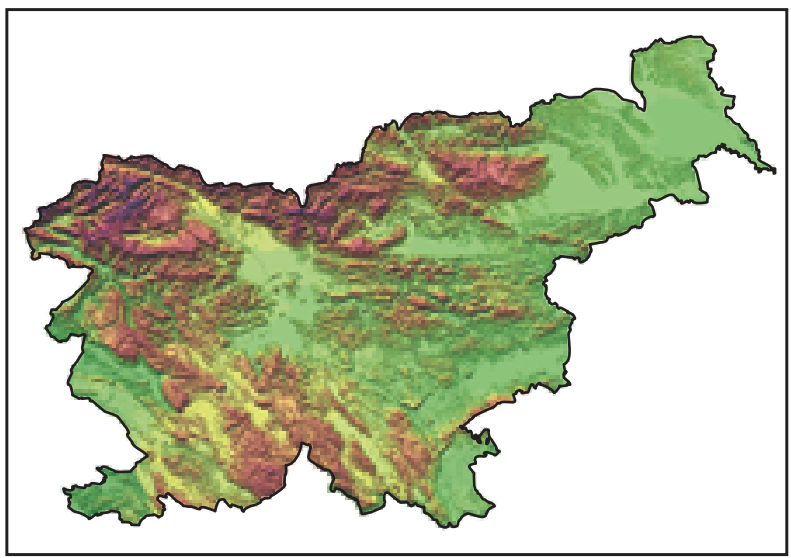




\section{Cartographic images of Slovenia through time}

UDC: $912.43(497.4)(091)$

528.9(497.4)(091)

COBISS: 1.02

\section{ABSTRACT:}

The territory of Slovenia appears on Europe's oldest maps. Slovenia's location at the junction of different natural and geographical units and various political formations influenced its traffic and border situation. As a result, for many centuries the territory of Slovenia appeared inaccurately on maps and as part of foreign national units. With the development of cartographical skills and the recognition of cartography in our area in the $16^{\text {th }}$ century and especially from the $17^{\text {th }}$ century on, Slovene territory was depicted equally on maps of the times through the efforts of Slovene and foreign individuals. At first, maps of individual Slovene regions dominated, but from the middle of the $19^{\text {th }}$ century there are more frequent depictions of the entire Slovene territory. Cartographical work thus also became a means of expressing national demands and hopes.

KEY WORDS: geography, historical geography, maps, Slovenia

The article was submitted for publication on October 5, 2006.

ADDRESS:

Primož Gašperič, B. Sc

Anton Melik Geographical Institute

Scientific Research Center of the Slovenian Academy of Sciences and Arts

Gosposka ulica 13, SI - 1000 Ljubljana, Slovenia

E-mail: primoz.gasperic@zrc-sazu.si

\section{Contents}

1 Introduction 247

2 Examination of maps according to periods 247

2.1 The Ancient World 247

2.2 The Middle Ages 248

2.3 Early Modern Times and Modern Times 250

3 Conclusion 259

4 References 259 


\section{Introduction}

Slovenes can be justifiably proud since in spite of numerical smallness and the small size of our national territory, from the viewpoint of our cartographical heritage we rank among the richest of nations. During our history we were under the wing of larger nations and various political formations. Our geographical location and national affiliations encouraged us to maintain contacts with Central and Southeastern European cultural currents. Above all, our inclusion in the Hapsburg empire for almost half a millennium enabled direct contact with neighbouring nations, which contributed to the improvement of cartographical techniques, methods, and the overall development of cartography in our region. German-speaking cartographers, including Slovenes, were considered competent and respected mapmakers from the start of the more advanced cartography of the Renaissance. Together with Dutch, French, and Italian cartographers they formed the driving force of European cartography.

Foreign cartographers began to delineate Slovene territory on maps more frequently at the beginning of the $16^{\text {th }}$ century, and more accurately from the second half of the $17^{\text {th }}$ century onward. The reasons for this included primarily the desire of individual countries to identify their territory, military requirements, the flourishing of printing techniques, and not least the need for maps that showed the lands of the newly discovered world. Due to the marginal political role of Slovene territory and its unfamiliarity, it was at first often drawn inaccurately and superficially on maps.

This situation changed in the $17^{\text {th }}$ century when Slovene and foreign mapmakers living in our territory began their own fieldwork surveying and describing individual parts of Slovene territory. The most frequent maps were of the Slovene provinces of Carniola, Styria, Istria, and Carinthia. For economic needs, numerous depictions of smaller areas also appeared in this period, most often in the form of very detailed and colourful theme maps (mines, roads, etc.).

With the nationalist awakening in the second half of the $19^{\text {th }}$ century, maps of Slovene ethnic territory began to appear. Austrian cartography, which in this period was among the best in the world, left a strong stamp on Slovenia. In the $20^{\text {th }}$ century, first as part of Yugoslav political formations and then as an independent country, Slovenia maintained and developed cartographical science in accordance with the most modern world standards.

In this article we wish to present a survey of the cartographical works that originated in various historical periods and show the territory of today's Republic of Slovenia through the beginning of the $20^{\text {th }}$ century. From the maps we can follow the social and economic development of areas in specific periods, as well as the level of development of cartography as a branch of science. Some examples of cartographical work are mentioned that only partially show Slovene territory to a greater or lesser extent but are interesting because of their historical, technical, or other features.

Another aim of the article is to present some basic characteristics of the maps, place them in a historical context, and thereby show the development over time of cartographical depictions of our territory.

\section{Examination of maps according to periods}

\subsection{The Ancient World}

In prehistoric times, the drawing of »maps « was a kind of artistic expression by individuals or groups that did not have much in common with later, especially modern cartographical work. At the time, »maps" were simply sketches of some objects, property, or parts of the natural environment in which the author lived. The pictures were drawn, scratched, or carved on various natural materials such as wood, bone, clay, stone, or the walls of caves. Due to climate conditions and the vulnerable materials and colours employed, the majority did not survive.

The oldest known »map « today, which was carved on a mammoth tusk discovered in Ukraine in 1966, dates to the twelfth millennium B. C. (Perko 2005). There is no doubt, however, that predecessors of maps existed much earlier. In the millenniums before Christ, civilizations such as the Babylonian, Egyptian, Sumerian, Phoenician, Chinese, and Indian developed mathematical and philosophical knowledge that aided them in conceptualizing and drawing their known worlds. Unfortunately, very few cartographical works from these periods survive today. 
The development of cartography in Europe began in antiquity. The ancient Greeks gave us cartography as a science and the first scientific foundations for drawing maps. Many of the famous scholars of the period were involved in ascertaining the shape and size of the earth and drawing it. In the $6^{\text {th }}$ century B. C., Anaximander drafted the first map of the known world, which unfortunately has not survived. In the $3^{\text {rd }}$ century B. C., Eratosthenes calculated very accurately the length of the meridian and on the basis of his discovery produced a map of the world. He was the first to draw a more complete geographical network on a map. Immediately after Dicaearchus, who was the first to place meridians and parallels on a map of the world, Eratosthenes added seven meridians and seven parallel latitude lines to his map. Around 100 B. C., Marinus of Tyre, who could be considered the father of mathematical geography, produced a map of the world that also has not survived. He compiled it on the basis of points of known latitude and longitude, which he calculated on the basis of itineraries (journey records). Claudius Ptolemaeus (Ptolemy) is the most famous geographer of antiquity. He lived in the $2^{\text {nd }}$ century A. D. and published the eight-volume Guide to Geography as well as maps of the then known world that have not survived in the original. Thanks to the Arabs, however, his writings were almost entirely preserved, and his maps of the world were reproduced in the most varied publications and editions during Early Modern Times (Vriser 1998).

After Ptolemy, ancient geography began to regress. In the Roman period, cartographical works were subordinated to the practical requirements of commerce, the military, and transportation. This conception resulted in graphic itineraries, maps that showed places and the exact distances between them while everything else about them was of lesser importance and therefore only very generally described.

Not a great deal of cartographical material has survived from antiquity. The reason lies in the small number of maps published and the long period that followed during which for various reasons they were not preserved. In this early period of cartography, Slovene territory was shown only as part of a wider area, and the Roman itineraries are of only limited help.

- Ptolemy's Geographike hyphegesis (Guide to Geography) from the $2^{\text {nd }}$ century comprises eight volumes. The first discusses general principles of cartography and methods of cartographical projection, while the next six books contain instructions for compiling maps and data about the geographical locations of settlements, rivers, and the like. The eighth book is a collection of twenty-seven maps of the known world of the time: a synoptic map of the world, ten maps of Europe, twelve maps of Asia, and four maps of Africa (Slovenci ... 1986). Although as mentioned Ptolemy's original maps did not survive, they were the basis of numerous later cartographical depictions at the start of Early Modern Times.

- The Hierosolymitanum or Burdigalense itinerary or the »Jerusalem Travel Journal« is the oldest known description of the route some Christians took to the Holy Land. It was written by an anonymous pilgrim who was probably from Burdigala (today's Bordeaux) in the years 333 and 334. The itinerary offers descriptions of places with brief comments written by the author during his journey. The pilgrimage began in Burdigala (Bordeaux) in France and its route continued across the territory of northern Italy, Slovenia, and the Balkan peninsula to Jerusalem and returned across the Italian peninsula (Internet 4).

- The Tabula Peutingeriana is a medieval copy of Castor's road map of the Roman Empire from the $1^{\text {st }}$ century A. D. The map is named after Konrad Peutinger, the Augsburg humanist who acquired it in 1508 (Goss 1993). The ma p comprises eleven sections (the original probably had twelve) thirty-four centimeters wide and totaling 6.8 meters long. Mainly roads marked in red and places with the possibility of accommodation are emphasized on the map. Relief is represented by a chain of light brown hills, and rivers appear as meandering green lines. Larger walled cities are marked with buildings and walls, while smaller places have a tower or only their names. The exceptions are Rome, Constantinople, and Antioch, which because of their importance are marked with divine images (Goss ibid.). Along the roads and paths, the distances between places are marked in Roman miles (Mihevc 1998).

\subsection{The Middle Ages}

The collapse of the western Roman Empire, the Migration of Nations, and the decline of Antique culture were followed by the Middle Ages. Its proverbial »darkness « is a reflection of the cultural regression that the Arabs somewhat mitigated with their activities and published works. In the period of ancient Rome, cartography did not advance qualitatively, although the Romans made Greek knowledge their own and incorporated or adapted it to their own needs. In the Middle Ages, this knowledge was forgotten, and later it was frequently contradicted and even rejected. Christian Europe only began to renew itself culturally 
with the rediscovery of the Antique and contact with neighbouring nations (Arabs). During the long and often difficult acceptance of Antique, Arabic, and other knowledge, the Catholic Church wielded great influence. With the help of monasteries, its organization, and the powerful influence it had, it became a sieve between the gradual discovery of other knowledge and cultures and Christian beliefs and dogma.

In cartography, the Christian vision of the world was asserted. The earth, which had a circular, oval, or rectangular shape, is a floating plate surrounded by sea. Most often, the authors of maps were monks from various monasteries so we call this period the age of monastery or monk cartography.

The so-called » $\mathrm{T}$ in $\mathrm{O}$ « maps, based on the Roman scheme of a circular world (Lat.: orbis terrarum), dominated this period. The world is divided into three parts: the upper half of the circle contains Asia, the lower left half contains Europe, and the lower right half contains Africa. The Mediterranean Sea, oriented north-south, forms the border between Europe and Africa, while the border between Asia and the lower half of the circle is the Don River, oriented east-west. These bodies of water between the continents form the letter $" T$, « its cross point coinciding with the location of the Holy Land. The »O $\mathrm{O}$ represents the surrounding sea (Fridl 1999). Aside from esthetically, these maps did not substantially influence the development of cartography. Along with them, we must mention the so-called »compass « maps of the late Middle Ages and the maps by Arab authors.

In $12^{\text {th }}$-century Europe, a slow but steady cartographical renaissance began based on the invention of »compass « maps or portolanos sailing charts and Ptolemy's work. Growing political and commercial contacts increased the need for such maps. For the period, the portolanos were very precise maps that accurately showed coastlines, harbours, and compass directions for navigation. During the Middle Ages, Arabic cartography achieved a high level of development based on Antique traditions and its own measurements, improvements, and findings. However, due to language, religious, and political differences, Arabic cartography had little influence on European cartography.

- In 1119, the cartographer Guido (Guido Pisanus) drew a map of the western Roman Empire. His map is very simple and due to its orientation toward the east with Rome in the center is reminiscent of the $» \mathrm{~T}$ in $\mathrm{O}$ « maps of the world. The borders between individual provinces are indicated with two parallel lines, and the inscription »Carantanos « appears in the area of today's Slovenia (Kärnten 1984). This map is probably the first cartographical work that mentions Slovene territory.

- In 1154, the so-called »Al-Idrisi« atlas was published. This is a map of the world composed of seventy sheets, oriented toward the south and in colour. Its author was the Moorish cartographer Al-Idrisi, who published it in Palermo. Measuring about $3.5 \times 1.5$ meters, it was made on the basis of climate belts (Internet 5). With this work, the author quite successfully presented the Arabic geographical experience of the Mediterranean region. Thanks to Arab seamen and merchants, the coasts on the maps are shown more accurately and the mountain ranges are drawn as low hills.

- Around 1235, the »Ebstorf map « was painted in the Benedictine monastery in Ebstorf. A coloured mural drawn by monks from Saxony and measuring $3.58 \times 3.56$ meters, it is the largest known map from the Middle Ages. It is oriented toward the east with Jerusalem at the center. Because it was destroyed during World War II, only photographs and reproductions exist today (Slovenci ... 1986). The map contains probably the first spelling example of »Carinthia« (Kärnten 1984).

- In 1439, a manuscript map of central Europe was produced that in 1491 was printed as a woodcut. Its author was Cardinal Nicolaus Cusanus, the bishop of Brixen, who followed the example of Ptolemy's maps. This map, whose original has not survived, remained known due to later manuscript copies and copperplate prints (Slovenci... 1986, Marković 1993). Oriented toward the north, the map shows the territory of Slovenia on its southern part.

- In 1459, the monk Fra Mauro created a large mural map of the world that is considered the foremost achievement of medieval cartography. Circular in shape with a diameter of almost 1.95 meters, it is more richly drawn and has greater detail than other maps of the period. Africa and Asia do not touch in the south and therefore do not close the Indian Ocean (Goss 1993). The locations and names of places in today's Slovenia are marked on the map.

- Erhard Etzlaub is the author of two pilgrimage maps. In 1492, he published a map labelled Daß ist der Rom Weg von meylen zu meylen mit puncten verzeychnet von eyner stat zu der andern durch deutzsche lantt, which covers a smaller area than his 1501 map labelled Das sein dy lantstrassen durch das Romisch reych von einem Kunigreych $z w$ dem andern $d y$ an Tewtsche land stossen von meilen mit puncten verzeichnet. For practical use, the maps were oriented toward the south (for easier use of Etzlaub's compass 
and because the goal of the pilgrimage is Rome, which is at the top of the map, right in front of the pilgrims). Mountain ranges and hills are marked with wide shaded belts, and places with circles and names. Roads are shown as lines of dots, each of which represents one German mile. On the first map, only the main routes leading to Rome were marked while on the second the network of roads is denser (Kärnten 1984).

- In 1493, the humanist and historian Hartmann Schedel published the Nuremberg Chronicle, which includes a woodcut map of the greater part of Europe made by Wilhelm Pleydenwurff and Michael Wolgemot (Kozličić 1995). The map is oriented toward the north, and the territory of present-day Slovenia and part of the Adriatic Sea appear on its southern part. Rivers are marked in the form of ribbons, mountains are indicated with small hills, and between them the names appear of only a few larger settlements.

\subsection{Early Modern Times and Modern Times}

In the period of the Middle Ages, it is hard to speak of uniform development and achievements in the field of cartography. Although the border between the Middle Ages and Early Modern Times is around 1500 , the beginnings of the cartographical revival stretch back to the $12^{\text {th }}$ century. There are many reasons for this: the use of the compass, conquering military expeditions, trade and cultural contacts, the rediscovery of Antique cartographical works, and to some extent Arab cartography, which reached its peak in this period.

Cartography reached a high point in the period of discovery that partly matches the turning point between the Middle Ages and Early Modern Times. Numerous journeys on land but above all on the seas (e. g., the expeditions initiated by Henry the Navigator) were the forerunners of change with the exploration of the unknown world. The expeditions of Diaz, Columbus, da Gama, Cabot, and later explorers returned with new measurements, descriptions, and knowledge that raised the desire and need for quality cartographical representations of the earth. To achieve this, it was necessary to improve the techniques for producing maps. Following Gutenberg's invention of the printing press with movable type, printing flourished during the $15^{\text {th }}$ century and together with cartography has continued to develop to the present day. The Renaissance was marked by truly rapid developments in both fields, and throughout the five centuries of Early Modern Times and Modern Times it has been the desire of every cartographer and mapmaker to create maps that reflect the earth's surface as realistically as possible.

At the beginning of Early Modern Times, exploration and the conquests of individual great powers drove the development of cartography. In the first half of the $16^{\text {th }}$ century, the Italians played a leading role in the development of cartography, with the Venetians at the forefront of development and exploration work. The works of G. Gastaldi and later V. M. Coronelli represent the peak of Italian cartography of this period. Spain and Portugal also produced high quality cartographical work. In the second half of the $16^{\text {th }}$ century, the Dutch seized the initiative in cartography. With their maps and atlases, A. Ortelius, G. Mercator, and later W. J. Blaeu marked the continuing development of cartography. The territory of today's Slovenia appears in all the major atlases of this period, for example, Coronelli's Atlante Veneto and Blaeu's Atlas maior sive cosmographia Blaviana (Korošec 1978). English cartographers and cartographers from central, mostly German-speaking Europe, particularly S. Münster and W. Lazius, were also very active in the $16^{\text {th }}$ century.

- Pietro Coppo's map of Istria dates from 1525. Coppo spent a great deal of his life in Izola and is the first cartographer from this part of the Adriatic region to publish a printed collection of maps (Kozličič 1995). He added his map to the Piran codex De summa totius orbis, a chapter from his extensive work De toto orbe from 1520.

The map of Istria shows the area of Slovenia, Istria, and Dalmatia and contains around 250 toponyms. Islands, the coast, bays, and the river network are shown quite accurately, but settlements in the interior of the peninsula are drawn disproportionately. The reason for this discrepancy is Coppo's unfamiliarity with certain areas of the peninsula (Marković 1993). From the cartographical viewpoint, the map is very well executed for the period and surpasses Münster's later Descriptio totius Illyridis. It is considered the highest quality cartographical depiction of the Istrian Peninsula until the middle of the $18^{\text {th }}$ century, and together with the codex it is preserved in the Sergej Mašera Maritime Museum in Piran (Mihevc 1998; Longyka 1999). 
- In 1542, Sebastian Münster's woodcut map Descriptio totius Illyridis was published. Originally measuring $34.0 \times 25.2$ centimeters, the map was appended to a collection of Ptolemy's Antique maps and first appeared in Münster's third expanded edition of Ptolemy's Guide to Geography (the first edition of Münster's version of Ptolemy's work was published in 1540). The map shows the area of Slovenia, part of Croatia, and western Bosnia. It is oriented toward the south, mountain ranges are represented by knolls, and along with the names of larger places appear the names of castles and monasteries. Most outstanding is the depiction of forest belts in the form of avenues that illustrate densely forested hills from Trnovo gozd across Hrušica, Snežnik, and Gorski Kotar to Bosnia. Clearly, there is an obvious similarity with Ptolemy's maps (Bohinec 1969; Mihevc 1998).

- Augustin Hirschvogel spent the last few years of his life (until 1553) preparing a map of Hungary that was only printed in 1565. It is one of the first military maps of Austrian territory (Korošec 1978). The original has not survived, but it is known due to numerous reprints, primarily taken from Ortelius's adaptation of the map in Theatrum Orbis Terrarum, and was probably the basis for many later maps of this region (Longyka 1999). Several of these are described below.

- In 1560, Giacomo Gastaldi published a map titled Geografia particolare d'una gran parte dell'Europa, nuonamete descritta cō i confini suoi, e prima uerso leuate e il meridian odi constantinopoli, e da ponetē il meridiano dela magca cita di Venetia etc. The map measures $83.5 \times 103.5$ centimeters and was produced by copperplate printing. It covers the area of the Balkan Peninsula, coastal areas are shown more accurately than the interior, and it is similar to his map of Hungary from 1456 (Marković 1993). Relief is shown with knolls that do not reflect the actual appearance of the surface. Some toponyms are distorted beyond recognition (Dörflinger 1977).

- In 1561, the Vienna cartographer Wolfgang Lazius published a collection of eleven maps titled Typi chorographici Provinciarum Austriae. First published individually, the maps were then published together and represent the first collection of so-called »special « Austrian maps. Slovene territory appears on four of the maps, which have the shape of an oval held by the two-headed Austrian eagle. One of the maps is named Ducatus Carniolae et Histriae una cum Marcha Windorum (»Duchy of Carniola and Istria with the Slovene March «) and is the first known separate representation of the Duchy of Carniola. Lazius was a historian and he saw in maps a way to present a country with illustrated images. Thus his maps emphasize historical features and neglect cartographical accuracy. He also produced the maps himself, which further contributed to their inaccuracy (Slovenci ... 1986; Longyka 1999). The data on Lazius's maps is relatively detailed but full of errors: they have no mathematical or geographical basis, they lack meridians and parallels, they are not drawn to scale, settlements are often in the wrong place, the flow of rivers is incorrect, and mountain ranges are only approximately depicted. In spite of all this, the maps are an important source of place names for the territory of today's Slovenia in the $16^{\text {th }}$ century. This had a great influence on foreign cartography, which along with detailed data also extracted numerous mistakes from his maps.

- In 1563, Venetian cartographer Giovanni Francesco Comocia drew a map that Ferando Bertelli later adapted and published in 1565 under the title Nova discrittione della Dalmatia et Crovatia. The map shows Slovenia, Istria, part of Dalmatia, Slavonia, and part of Bosnia (Slovenci ... 1986). Bertelli's map differs from the original only in its method of execution. The graphic representation is more delicate, evident in the depiction of relief, seacoasts, and rivers that are drawn with thin lines (Markovic 1993).

- In 1569, the map Ducatus Carniolae una cum Marchia Windorum (»The Duchy of Carniola with the Slovene March «), a 32.2 × 42.3 centimeter copperplate by the Venetian Bologninus Zalterious, appeared (Orožen 1901). The author modeled his work on Lazius's map Ducatus Carniolae et Histriae una cum Marcha Windorum. The map is characterized by Venetian graphics and data from Austrian maps of the period (Marković 1993).

- In 1570, Abraham Ortelius included the map Schlavoniae, Croatiae, Carniae, Istriae, Bosniae, finitimarumque regionum nova descriptio (»A new description of Slavonia, Croatia, Carniola, Istria, Bosnia, and neighbouring regions") in the first edition of his atlas Theatrum Orbis Terrarum. It is an adaptation of Hirschvogel's map of Hungary, which Ortelius also included in his collection in a smaller format. The upper part of the map shows the area between Lake Osojsko and the central Danube River, and the lower part the area between the Adriatic Sea and Sarajevo and Višegrad. The Adriatic coast and islands are very similar to Ptolemy's map, and the interior is more accurately depicted since Hirschvogel was more familiar with it. The Sava River runs from the west straight eastward and has more correctly drawn 
and named tributaries than other maps of the period. Cerknica Lake is the proper size, and mountain ranges are indicated with hillocks. Settlements are shown along with cities, monasteries, churches, and castles, but many times their locations and the distances between them are incorrect. In the third edition of his atlas in 1573, Ortelius drew upon Pietro Coppo's Histriae tabula (Istria and its surroundings) and Wolfgang Lazius's maps Carinthiae ducatus, et Goritiae palatinatus (Carinthia and Goriško) and Goritiae, Karstii, Chaczeolae, Carniolae, Histriae, et Windorum marchae descrip. (»A description of Goriško, Kras, Kočevsko, Carniola, Istria, and the Slovene March «). The latter originally measured $23.2 \times 31.0$ centimeters. Ortelius's version of this map coincides with Lazius's map with only the outermost part of Istria drawn from other sources. The many Slovene place names give the map great significance. Unfortunately, like other maps by Lazius and maps that draw upon his work, it contains many errors due to the incorrect location of places and fictitious and modified data (Slovenci... 1986).

- In 1572, Ioanes Sambucus (Jänuos Zsämboky) created the map Illyricum, basically an improvement of Hirschvogel's Hungary map, in approximately $1: 1,200,000$ scale and measuring $46.6 \times 35.6$ centimeters. Ortelius published the map in 1573 in the second edition of Theatrum orbis terrarum. In many cases (for example Istria), areas are more exactly drawn, although the map still shows the influence of Ptolemy's map in its shape and data. Sambucus was Lazius's successor in the field of cartography. He collected ancient references and maps that he adapted, corrected, and republished (Bohinec 1969, Marković 1993).

- In 1589, the map Karstia, Carniola, Histria et Windorum Marchia (»Kras, Carniola, Istria, and the Slovene March «) by Gerardus Mercator was published in a collection of a larger number of maps and originally measured 38.0 c 49.0 centimeters (Marković 1993). Mercator drew his data for the area of Slovenia from maps by Ortelius and Lazius (for example, Ducatus Carniolae et Histriae una cum Marcha Windorum). As a result, it contains numerous inaccuracies. A good example is the nonexistent Planinska River (Alben fluvius) that springs east of Logatec and flows into the sea near Koper. Mountain ranges are shown with molehills, forests with groups of trees, and settlements are marked with circles.

- In 1612, Israel Holzwurm produced Archiducatus Carinthiae fertilissimi Carantania olimet Carnia, dicti, ex diligenti omnivum Locorum Perlustratione et Dimensione, noua, vera, et Exactissima Geographia, a map of Carinthia. In 1616, the map was republished (the first edition is believed lost) in smaller scale, approximately 1:593,000. In spite of its size, it is quite accurate and has a great deal of topographical information. Rivers, streams, and lakes are surprisingly well presented, and hills are shown with molehills whose size indicates height. Roads are not marked, although bridges across the Drava/Drau River are. The borders between provinces are marked with dotted lines. Places and individual areas such as winegrowing areas and hot springs are shown by fifteen different symbols, and mines have their own signs (Kärnten 1984).

- From 1635 on, the Dutchman Willem Janszoon Blaeu and his sons Johannes and Cornelius published Theatrum Orbis Terrarum, sive Atlas Novus. Their work was initially a continuation and improvement of the works of Ortelius and Mercator, although later their atlas grew into an independent opus. Thus like other areas, Slovene territory appears on numerous maps that draw primarily on the work of Ortelius and Mercator.

Derivations from Mercator's maps that show Slovene territory are also contained in the atlases of Jodocus Hondius and Johannes Janssonius. The Hondius family inherited Mercator's printing plates and his maps.

- In 1657, Nicolas Sanson produced the map Hertzogthūber Steyer, Karnten, Krain \& c. Duchés de Stirie, Carinthie, Carniole (»Duchies of Styria, Carinthia, and Carniola»). The map covers the area between Upper Styria and Istria and the area between Piava and Lake Balaton. The latitude-longitude grid is not correct, but the depictions of coasts, mountains, and waterways are close to actual conditions. The area of Slovene territory shows the influence of Lazius's inaccurate maps (Bohinec 1969; Slovenci ... 1986). Sanson is the most important French cartographer of the $17^{\text {th }}$ century and was royal geographer under Louis XIII and Louis XIV. With his sons he produced many maps that were prepared for publication by the French cartographer Charles Hubert Jaillot. These maps were published in a very large format atlas.

- In 1678, the priest, cartographer, and topographer Georg Matthäus Vischer published a map titled Styriae Ducatus Fertilissimi Nova Geographica Descriptio (»A New Geographical Description of the Most Fertile Duchy of Styria «). Measuring $123.5 \times 135.5$ centimeters, the map is composed of twelve parts. It was engraved in copper by Andrej Trost. The map does not give a completely true picture of the province but due to individual improved elements it was very important for the advancement of the cartography of the period. River networds and lakes are very well marked, elevations are shown with hills and 


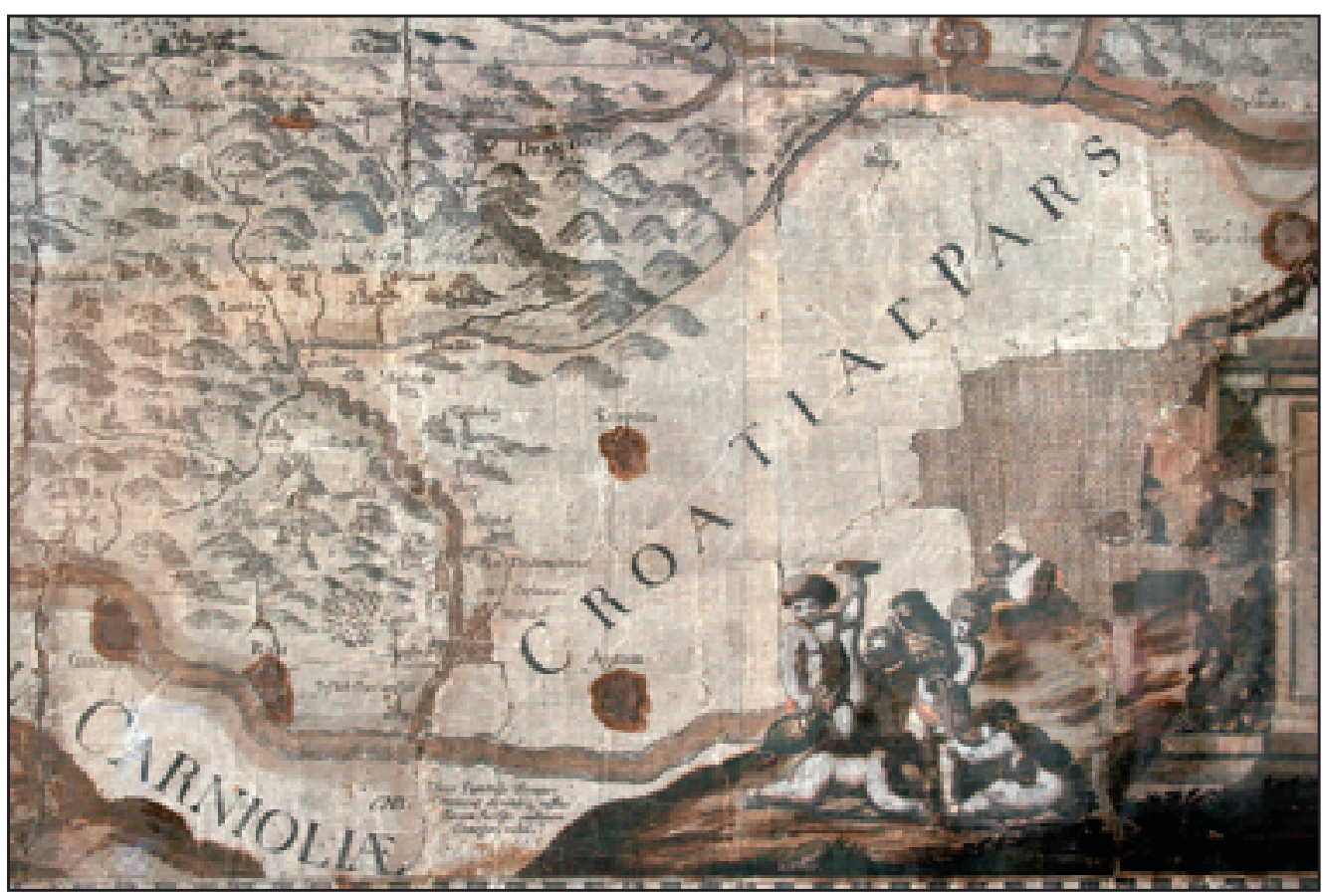

Figure 1: Section of Styriae Ducatus Fertilissimi Nova Geographica Descriptio. Georg Matthäus Vischer, 1678. Map Museum of the Anton Melik Geographical Institute of the Scientific Research Centre of the Slovenian Academy of Sciences and Arts.

shaded hills, and borders are generalized due to the author's unfamiliarity with them and political conditions. The map shows Styria and only exceptionally are settlements outside its borders marked. Settlements are marked with various cartographical symbols. Cities are shown with ground plans with recognizable features such as fortifications, towers, or castles. Smaller settlements are marked more superficially. Distances, proportions, and projection points are frequently incorrect and therefore the scale of the map varies from $1: 160,000$ to $1: 172,800$. The castles and manors of all the more important nobles are drawn on the map, while less important estates are marked with simple topographical signs or are generally unmarked. The map's rich illustrations and texts that fill empty spaces give the map a powerful visual impact. All the depictions reflect events and features the author believed were necessary to portray. On the sixth page he depicted the victory of the Austrian army over the Turks in 1664 near St. Gotthard with an illustration of the Archangel Michael fighting a dragon. Drawn on the ninth page near the legend and scale are numerous measuring instruments that Vischer used in producing the map. In addition there are two images of angels: one holds a picture of the author, and the second a jumping fish, an allegory of the author's name (Vischer/»fisherman«). The map is similar to those by Mathäus Merian (father and son) and Janez Vajkard Valvasor (Korošec 1978; Stopar 2006).

- The polymath Janez Vajkard Valvbasor published Glory of the Duchy of Carniola in 1689. It contains a map of the Duchy of Carniola that Valvasor himself produced. The map is a somewhat modified version of the map Carniolia, Karstia, Histria et Windorum Marchia that Valvasor made in two versions in 1681 for the historical work Carniolia antiqua et nova by Janez Ludvik Schönleben. The first version is a map of the Carniola of the period, and the second is a historical map. The basis for Valvasor's map was taken from a Merian map that was a copy of Mercator's Karstia, Carniola, Histria et Windorum Marchia. Valvasor improved the depiction of the river network in particular, but his depiction of Istria was a step backward that did not follow the example of Coppo's map of Istria (Longika 1999; Rojc 1990). In spite of the graticule, the map is distorted, and the location of mountain ranges, which are depicted with shaded molehills, is inaccurate. However, the size of Cerknica Lake is correct, and in spite of the errors it contains the map assists the orientation of readers of Glory of the Duchy of Carniola. Valvasor also depicted Carniola 


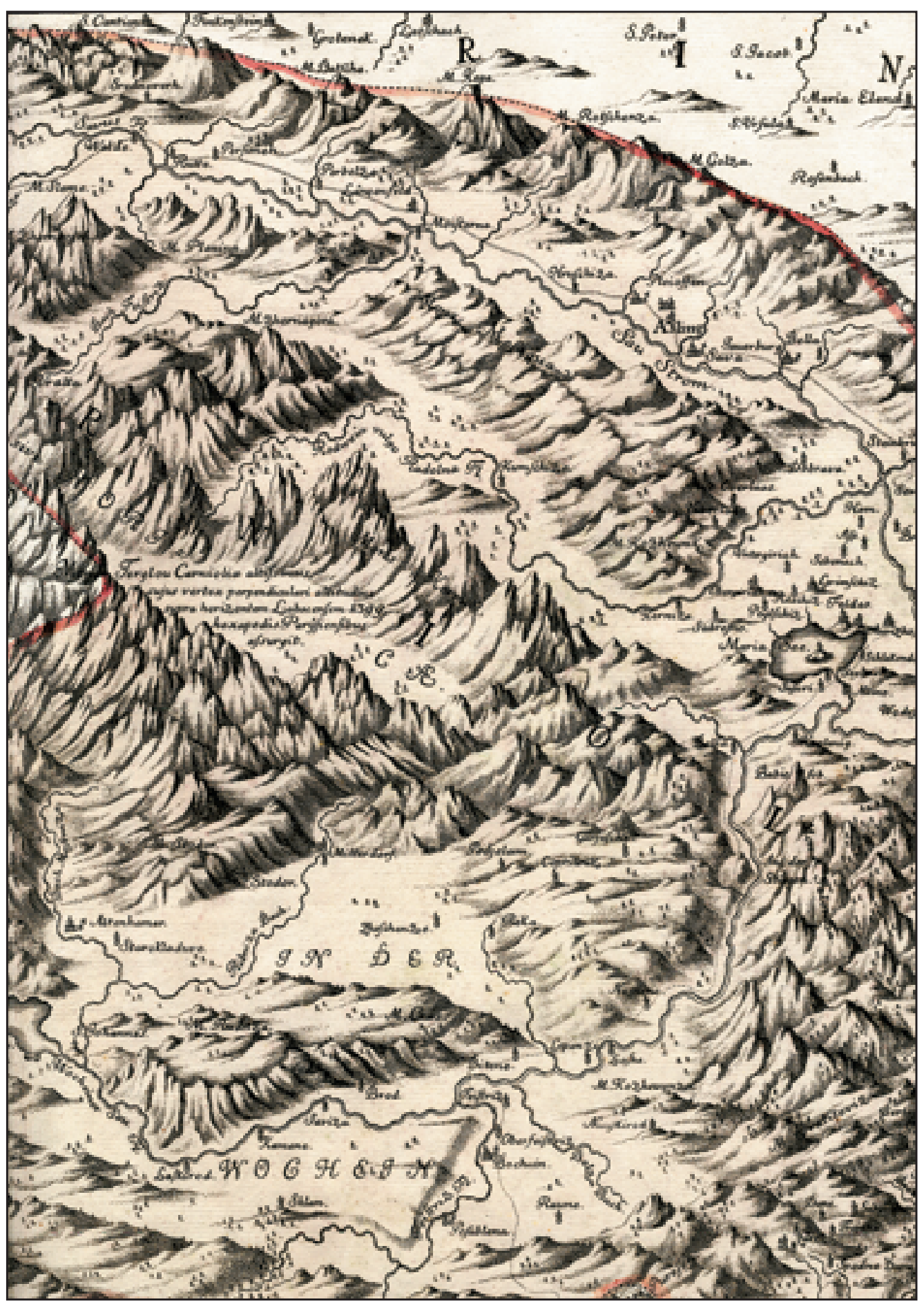

Figure 2: A section of Ducatus Carnioliae tabula chorographica. Janez Dizma Floriančič, 1678. Map Museum of the Anton Melik Geographical Institute of the Scientific Research Centre of the Slovenian Academy of Sciences and Arts. 
on the five maps of administrative units that he included in the second volume of Glory of the Duchy of Carniola.

- In 1690, Giacomo Cantelli da Vignolla published Parte della Schiavonia, Overo Slavonia, agivnavi la Contea di Cillea, e Windisch Mark abitate da Popoli Slauini a Slavi ò descritta da Giacomo Cantelli da Vignola, which showed the territory of Slovenia east of a line through Maribor, Litija, and Cerknica Lake, western Slavonia, and part of Croatia north and south of the Kolpa River. Cantelli found a great part of the data for his map on a map of Croatia from 1673 by Stjepan Glavač (Marković 1993). Relief is shown with a stenciled distribution of molehills, and several forested regions are marked by groups of trees. The map gives a good picture of the Drava and Sava watersheds with their tributaries, but Cerknica Lake is too big and located too far east.

- Between 1716 and 1724 (the exact date is unknown), the Nuremberg cartographer Johann Baptist Homann produced the map Tabula Ducatus Carnioliae, Vindorum Marchiae et Histriae (»Map of the Duchy of Carniola, the Slovene March, and Istria «). The map does not represent an advance in technique or content and is only a graphically improved copy of Valvasor's map of the Duchy of Carniola (Korošec 1978). A city plan of Ljubljana and a map of Cerknica Lake were added to the map. Homann produced many maps that partially show Slovene territory. His map of Styria (Ducatus Stiriae Novissima) is a reduced adaptation of Vischer's work that covers the Slovene part of Styria and part of Carinthia. A map of the Duchy of Carniola was later upgraded and reprinted by Homann's student Mathias Seutter. Seutter also published Carinthia Ducatus (»Duchy of Carinthia«), which in addition to other areas also included a section of Carniola to a line through Bohinj, Radovljica, and Kamnik (Slovenci... 1986).

- In 1744, the priest Janez Dizma Florjančič published the map Ducatus Carnioliae tabula chorographi$c a$ (»Chorographic Map of the Duchy of Carniola «), the highest quality and most complete map of Carniola from this period. It was composed of twelve parts that varied somewhat in size and measured approximately $45 \times 62$ centimeters. The size of the entire map is almost $180 \times 188$ centimeters. The map covers the area from Gorica (Gorizia) and Gradišče (Gradisca) in the west to Žalec, Brežice, and Karlovac in the east and from Tarvisio, Eisenkappel, and Slovene Gradec in the north to Rovinj and Crikvenica in Croatia in the south. The map includes a latitude-longitude grid with a prime meridian running through El Hierro Island in the Canaries. The scale varies somewhat in different parts of the map but is approximately $1: 100,000$. The map is executed in a perspective method and is distinguished by a remarkably expressive presentation of relief. Hills are indicated by molehills while higher mountains appear as more conical shaded peaks. The hydrographic network is drawn more accurately than on the map's predecessors, individual trees or groves of trees are used to indicate forests, and winegrowing areas are marked with grapevines. Numerous place names appear on the map, and many settlements are marked by various symbols (e.g., circular walls, churches) that are defined in the legend. The main weakness of the map is the road network since many roads are not shown although the most important ones are marked with single or double dotted lines (Reisp 1995; Longyka 1999). The skyline of Ljubljana in the upper right corner is a special feature of the map. The city plan is very accurate and was the first published. The lower right corner of the map makes a powerful impression on the user with its Baroque decorations depicting allegorical figures such as gods and water pitchers and features of the province such as a puttos pouring iron. The map was engraved on copperplate by the Ljubljana engraver Abraham Kaltschmidt, who added his signature below the city plan of Ljubljana. This map ranks among the highest achievements of cartography and surveying as well as at the peak of the graphic arts of the period.

- In 1752, Didier Robert de Vaugondy published the map Partie Méridionale du Cercle d'Autriche, qui comprend La Basse Pertie du Duché de Stirie, Le Duché de Carinthie, divisé en haute et basse, Le Duché de Carniole, divise en haute, basse, moyenne et inter. Carniole, et l'Istrie Impériale. The map shows the southern part of the Austrian Empire of the period. Some areas, such as Kras and Dalmatia, are drawn more accurately than on other maps of the period, from which we can assume that the author did not follow the example of Mercator's maps but rather the cartographical work of Giovanni Antonio Magnini, who knew this area better. (Lago 1996).

- Around 1760, the Atlas novus appeared which included Conrad Tobias Lotter's map Exactissima Ducatus Carnioliae, Vindorum Marchiae et Histriae delineatiocura et caelo Tob. Conr. Lotter. The maps in this atlas are superficially done and are not significant for the advancement of cartography. They are also unreliable since the borders between provinces and the locations of individual place names and other features are frequently drawn incorrectly (Orožen 1901). Lotter was the son-in-law of Matthias 
Seutter and took over his company. He erased Seutter's name from the old printing plates and replaced it with his own (Slovenci... 1986).

- Between 1763 and 1787, the so-called Joseph II military land survey maps were created. Two versions of each section were made, the original and a copy. The individual maps measure $64 \times 42$ centimeters with a scale of $1: 28,800$. At the end of the $18^{\text {th }}$ century, they were considered the most detailed and highest quality cartographical works. Compiled on the basis of the first geodetic survey of the Habsburg Monarchy, they were strictly guarded military documents and were not available to the general public. The maps are very detailed with the names of hills, valleys, and rivers written in the local languages. Because they were military maps, the terrain is clearly presented. Hills and elevations with their steep and more gently sloping sides, mountain slopes, and valleys are accurately drawn. The distribution of forests, the direction of river currents, cultivated land, and other features are marked everywhere. The cultural landscape is also presented accurately, showing every type of settlement, buildings, roads, and even roadside shrines. The clarity of the maps is achieved through precise drawing and the use of various colours. It is interesting that the sites of natural resources (mines, saltworks) and iron foundries are not marked by symbols but rather with words. The status of cities is indicated by the size and format of the lettering and in places is added to the name (Rajšp 1994).

- In 1778, the first volume of Balthazar Hacquet's Oryctographia Carniolica oder physikalische Bescheibung des Herzogthums Krain, Istrien und zum Theil der benachbarten Länder was published, which contained a map with no caption titled simply Krainska deschela (»Map of Carniola «). Cartographically, the map is old-fashioned, but it is distinguished by the marking of quarry and mines sites and its Slovene toponyms. Only a few German or Latin names are used. Hacquet's maps are the first geological theme maps of Slovene territory (Longyka 1999).

- In 1782, Hacquet's produced Mappa Litho- Hydrographica Nationis Slavicae (»Lithographical and Hydrological Map of Slavic Nations «). Elaborated by Leopold Lieber on the basis of Hacquet's material, this theme map was included in the third volume of Hacquet's natural science work Oryctographia Carniolica in 1784. This 1:420,000 scale map has an oblong form and shows the area between the watersheds of the Drava and Sava rivers. The Alps and the Karavanke Mountains are depicted with perspective technique and shading. The Pohorje mountain range in Slovenia and the Dobratsch mountain range in Carinthia are shown by so-called "caterpillars. "The watersheds of the two rivers and larger settlements are drawn correctly, and a special feature is the marking of the locations of minerals. Place names are not given in just German or Italian but mainly in Slovene or bilingual versions (Wawrik et al. 1989).

- In 1788 and 1791, the first and second volumes of the dramatist Anton Tomaž Linhart's historical work Poskus zgodovine Kranjske in ostalih delov Južnih Slovanov were published. Two maps were added as an appendix: Tabula Antiqua regionis inter Dravum Fluvium et mare Adriaticum (»Map of the Territory between the Drau/Drava River and the Adriatic Sea in Antiquity«) and Conßpectus Karantaniae ßive Slavorum meridionalium ante Caroli M. imperium (»Map of Carantania or Southern Slavs before the Empire of Charlemagne «). The maps present the same region in different historical periods. The first map is larger, drawn in larger scale and with more cartographical detail. Mountains and hills are indicated by shaded molehills and lower elevations with hatches. The second map has fewer toponyms, roads are not described, and the relief is stenciled with lightly shaded molehills.

- Between 1789 and 1797, Joseph Karl Kindermann created a series of maps that were included in his Atlas von Innerösterreich (Die Provinz Inner-Oesterreich). The atlas covers the provinces of Inner Austria: the duchies of Styria, Carinthia, and Carniola, the county of Gorica (Gorizia) and Gradiščanska (Gradisca), and the then Austrian-controlled coast. It consists of eleven $1: 255,000$ scale maps and a survey map of the Inner Austrian provinces with a 1:600,000 scale. The surface relief is very well depicted on the maps and various types of settlements are marked, as are the language borders between Slovenes and Germans in Carinthia and Styria ((Korošec 1978; Wawrik et al. 1989).

- In 1812, Joseph de Castro published Carte von Inner-Oestrreich nach den neuesten astronomischen Ortsbestimungen und andern Hülfsquellen gezeichnet von Joseph de Castro, which shows Styria, Carniola, and Istria. It comprises six parts with approximately $1: 290,000$ scale (Dörflinger 1988). The name, legend, and scale are written in German and French while the toponyms on the map are in German. Similar to Castro's map but with a larger scale is the Charte von dem Königreiche Illyrien und dem Herzogthume Seyermark nach de Castros Charte von Inneroestreich entworfen von C. F. Weiland published in 1925 by 


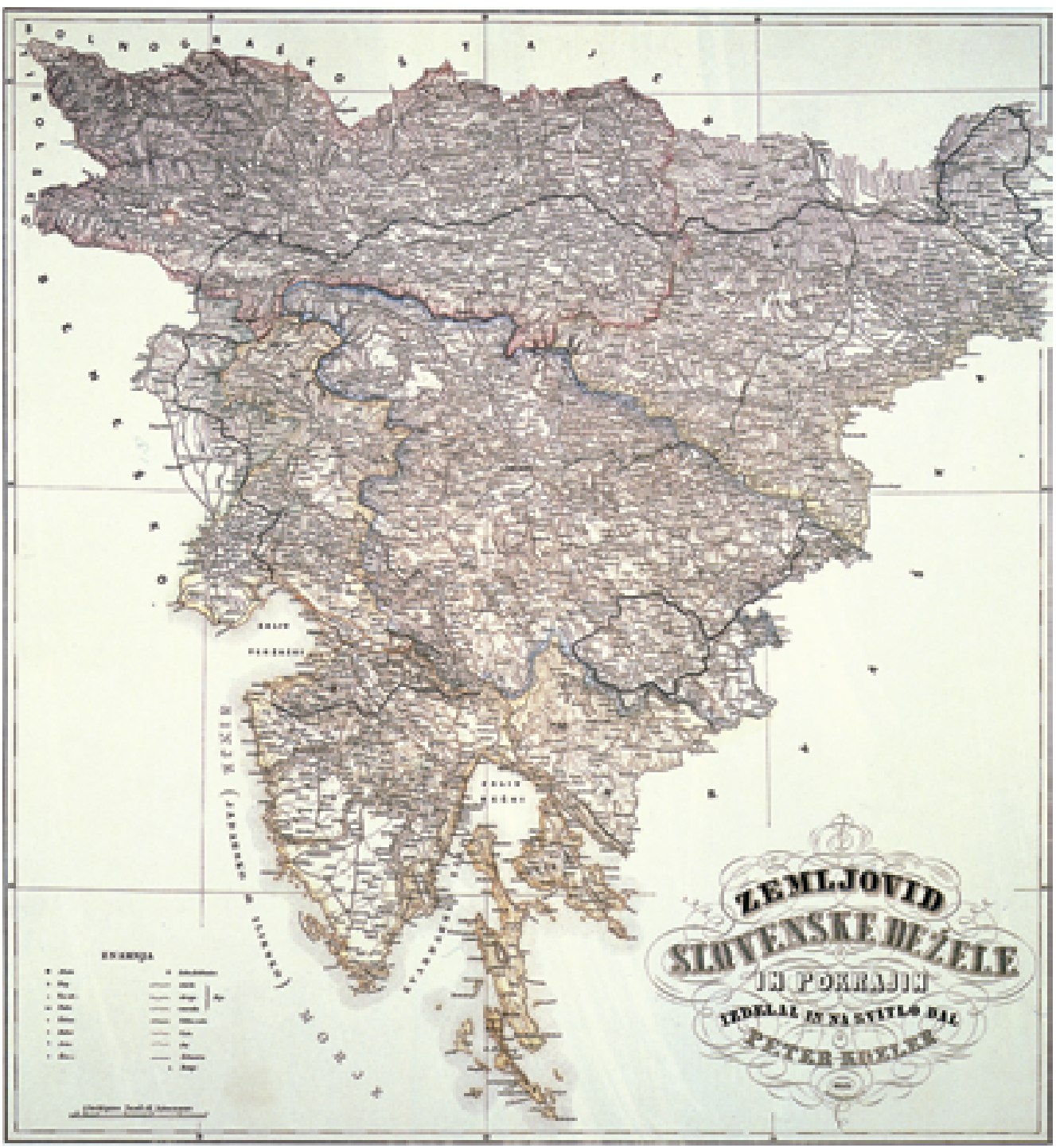

Figure 3: Zemljovid slovenske dežele in pokrajin (»Map of Slovene territory and regions«). Peter Kozler, 1853. Map Museum of the Anton Melik Geographical Institute of the Scientific Research Centre of the Slovenian Academy of Sciences and Arts.

the Saxon geographer Carl Ferdinand Weiland. Due to the density of toponyms the map is more difficult to read.

- In 1832, the military surveyor Gottfried Loschan published the first edition of Karte von Herzogthume Krain (»Map of the Duchy of Carniola «). The map was commissioned by the Agricultural Association of Carniola and is the first map to be drawn consistently on the basis of the Austrian general headquarters provincial maps (Korošec 1978). The scale is $1: 288,000$, and the relief is shown with precise hatching, well executed and clearly visible. Due to its exclusively German place names, black and white colour, and general content, this map is very legible compared with Freyer's later Specialkarte (See below.). In 1844, the map was published under the same name but improved and widened to cover all of the Illyrian Kingdom (Orožen 1901, Longyka 1999). At the side of the map, plans of Ljubljana and Trieste were added. 
- Between 1844 and 1846, Henrik Karl Freyer published the sixteen sheets of Specialkarte des Herzogthums Krain (»Special Map of the Duchy of Carniola «). The scale of the maps, which are based on the Austrian general headquarters map from 1834, is $1: 113,500$. The printing was done using the new, five-colour lithography technique. The relief is shown by shading, Rivers, streams, roads, and cart trails are drawn very accurately but some bridges and ferries are missing. To Freyer's credit, the map is extremely rich with local Slovene place names, and almost half of the names have the German versions added. There are symbols for quarries, mines, and montane objects. The latter are defined in a legend titled »Fossils and Montane Symbols. « Also marked are highlands, to which the author has added altitudes in places or marked with small triangulation points. In spite of having a German name, this map is the first Slovene wall map. It is considered an upgraded successor to Hacquet's lithological map and the best work of Slovene cartography prior to Kozler, who used it as a reference in creating his own map (Orožen 1901; Korošec 1978; Longyka 1999).

- In 1852, Peter Kozler published Zemljovid slovenske dežele in pokrajin (»Map of Slovene territory and regions «), which bore the date 1853. The map shows the territory of Carinthia, Carniola, Primorska with the Kvarner Islands, part of Styria, Prekmurje, Beneška (»Venetian«) Slovenia, and Vojna krajina, the march province in Croatia. The $1: 288,000$ scale Austrian military maps were the basis for the map, but Kozler reduced the scale to $1: 576,000$. The first edition used the copperplate technique, and the outside edge measured approximately $50 \times 55$ centimeters. To represent topographical features, he employed Johann Georg Lehmann's technique of hatching and shading relief, which at the time was considered quite modern. The Vienna cartography department of the Military Geographical Institute had begun to use this method on its maps several years earlier. The map is rich with data: cities, boroughs, villages, postal stations, and iron, copper, lead, and mercury mines are all drawn on the map. The river and road networks, railways, mines, borders, and places are marked with military topographical symbols in black, which is also used for local and regional names. The small scale and the number of names reduce the readability of the map, so for the reprint Kozler decided to use colour to mark the borders and regions. It is the first map of Slovene ethnic territory on which the names of places appear exclusively in the Slovene language (Korošec 1978, Kranjec 1964). Toward the end of 1852, Kozler announced in the newspaper the possibility of pre-ordering the map, which would be published in 1853 . The map was printed before the end of 1852 but the authorities of the period, operating under the influence of interior minister Alexander Bach's absolutism, banned the map due to its emphasis on Slovene identity. The printing plates were confiscated along with all the printed copies, and Kozler was tried for high treason. Several months later, Kozler was acquitted of all charges, and following his special appeal all the confiscated material was returned in 1856. The distribution of the map was only allowed in 1861. Due to its nationalist character and the quality of its cartographical depiction, the map appeared in many subsequent editions. The second and third were published in 1864, the fourth in 1871, the fifth in 1975, the sixth in 1978, and the seventh and eighth in 1992 and 1995 (Korkiš and Škufca 1996). Since the first printing, details on the map (e. g., colours) have changed somewhat and smaller border areas in Croatia and Styria were added. The most important appendix, which was planned for 1853 but added to the second edition in 1864, was the Registry of Cities, Boroughs, and Settlements. For many years, this registry was the only list of settlements covering all of Slovene ethnic territory.

- In 1856, the General-Karte des Oesterreichischen Kaiserstaates mit einem grossen Theile der angrenzenden Länder (»General Map of the Austrian Empire with Parts of Bordering Countries«) was authored by Josip Scheda, at that time head of the Military Geographical Institute in Vienna. The map comprises twenty sections with a $1: 576,000$ scale. The cartography is very good since the relief is very well depicted, but its readability is limited by the density of toponyms (Marković 1993).

Cartographical activity in Europe in the second half of the $19^{\text {th }}$ century, particularly toward the end of the century, became largely nationally oriented. Its development was frequently guided by political and nationalist trends in individual political formations. Both branches of modern cartography, military and civilian, became tools in the hands of governments and their armed forces. The development of cartographical techniques and methods of representation in this period was almost exclusively in the hands of military geographical and cartographical institutes that were also the only organizations with sufficient capital, trained and qualified staff, equipment, and access to data. Civilian cartographical activity was only to contribute to a certain degree and extent to the achievements of military cartography. In spite of this, 
with the help of the ever increasing dispersion of geographical knowledge and the development of geodetics, civilian cartography gradually developed as an equal partner.

- In the 1860 's, Blaž Kocen, an Austrian geographer of Slovene birth, was particularly active. He is known primarily for producing a school atlas and two geography textbooks (Žagar 1973). He also produced numerous wall maps and regular maps, including maps of Slovene provinces: Carniola with Istria, Styria, and Carinthia. His maps are distinguished by a clear presentation of relief and the settlement network (Bratec Mrvar 2007).

- Between 1873 and 1889, the Specialkarte der österreichisch-ungarischen Monarchie im Masse 1:75,000 (»Special Maps of the Austro-Hungarian Monarchy in 1:75,000 scale«) were published. They were produced by the Military Geography Institute in Vienna to serve both military and civilian uses and were the basis for many later topographical and theme maps. To cover the entire Monarchy, 715 sections were done in the 1:75,000 scale. Each section covered an area of 30 minutes of longitude and 15 minutes of latitude. The diversity of relief was shown with contour lines and hatching (Petrca et al. 1974, Marković 1993).

- In 1879, Carl Friederich Baur created the 1:150,000 scale Herzogthum Krain (»Duchy of Carniola«) wall map. Done in German and Slovene, the map is sufficiently readable in spite of the double naming of settlements. The relief is hatched, the sea and larger lakes (Bohinj, Bled, Cerknica) are coloured blue, rivers are indicated with thicker or thinner black lines, and some lowlands such as the Ljubljana and Celje basins are coloured green. Roads are shown as two parallel lines, and settlements are distinguished according to size with symbols ranging from thin circles to variously-sized filled circles.

- At the beginning of the $20^{\text {th }}$ century, the members and editorial board of Slovenska matica, an organization established to support and foster the Slovene identity, realized it was necessary to produce a newer and higher quality map of Slovene territory than Kozler's. Work on the new map, which began at the end of the $19^{\text {th }}$ century and was based on one of the Austrian general headquarters maps, was protracted due to internal problems at Slovenska matica and came to a complete halt with the start of World War I in 1914. Work continued after the war, and in 1921 the 1:200,000 scale Zemljevid slovenskega ozemlja (»Map of Slovene Territory«) was published, and a year later the Index of Settlements on the Map of Slovene Territory. The map features a great density of place names and is therefore somewhat difficult to read (Kranjec 1964).

\section{Conclusion}

The article provides a survey several dozen maps that partly or entirely include the territory of today's Slovenia. The older maps show Slovene territory as part of a wider area, a consequence of the relatively small political and social recognition of the Slovene nation in past historical periods. Maps that originate in the $17^{\text {th }}$ century and especially from the $18^{\text {th }}$ century on mostly present larger or smaller parts of the area of Slovenia and its surroundings. This method of depicting Slovene territory coincides with the development of cartography and the cartographical awareness of Slovenes that at least at the start of the period was based on the work of Slovene and foreign individuals.

The descriptions are arranged in chronological order based on the year of origin of the maps or of their publication. The descriptions are based on numerous sources in the literature. Some items vary in the literature (date of origin, first mention of specific data, the scale and size of maps, names of authors, titles of maps, etc.). In such cases, we relied on the newest sources, on the assumption that the authors personally examined the original maps. Where the cartographical material was difficult or impossible to access, we followed the literature exclusively.

The list of cartographical works that show the territory of today's Republic of Slovenia reflects the national desire of Slovenes to keep pace with other nations and through cartography to express their desire for equality and self-preservation. Today, through the maps it has produced and its ongoing projects, Slovenia's highly developed modern cartography continues to meet these goals.

\section{References}

Bohinec, V. 1969: Slovenske dežele na zemljevidih od 16. do 18. stoletja. Ljubljana.

Bratec Mrvar, R. 2007: Blaž Kocen: življenje in delo. Šentjur 
Dörflinger, J., Wagner, R., Wawrik, F. 1977: Descriptio Austriae - Österreich und seine Nachbarn im Kartenbild von der Spätantike bis ins 19. Jahrhundert. Wien.

Dörflinger, J. 1984: Österreichische Karten des 18. Jahrhunderts. Österreichischen Akademie der Wissenschaften. Wien.

Dörflinger, J. 1988: Österreichische Karten des 19. Jahrhunderts. Österreichischen Akademie der Wissenschaften. Wien.

Fridl, J. 1999: Metodologija tematske kartografije nacionalnega atlas Slovenije. Ljubljana.

Goss, J. 1993: The Mapmaker's Art. An Illustrated History of Cartography. Chichago.

Internet 1: http://sl.wikipedia.org/wiki/Ptolemej (12.7.2006)

Internet 2: http://en.wikipedia.org/wiki/Itinerarium_Burdigalense (31.8.2006)

Internet 3: http://www.romanroadmap.com/Map_of_Roman_Empire.html (31.5. 2007)

Internet 4: http://198.62.75.1/www1/ofm/pilgr/bord/10Bord01MapEur.html (6. 6. 2007)

Internet 5: http://www.henry-davis.com/MAPS/EMwebpages/219mono.html (13.6. 2007)

Kärnten in alten Landkarten bis 1809, 1984: Der 100-Jahr-Feier des Landes museums für Kärnten 1884-1984. Landesmuseum für Kärnten. Klagenfurt

Kladnik, D. 2005: Zemljepisna imena v Atlantu in njihov pomen za sodobno imenoslovje. Atlant. Ljubljana.

Kordiš, I., Škufca, I. 1996: Peter Kozler in prvi zemljevid slovenskega ozemlja. Kočevje.

Korošec, B. 1978: Naš prostor v času in projekciji. Ljubljana.

Kozličić, M. 1995: Kartografski spomenici hrvatskoga Jadrana. Izbor karata, planova i veduta od kraja 17. stoljeća. Zagreb.

Kranjec, S. 1964: Geografija. Slovenska matica 1864-1964, str. 195-219. Ljubljana .

Lago, L. 1996: Stare karte Jadrana. Pula.

Linhart, A. T. 1788: Poskus zgodovine Kranjske in ostalih dežel južnih Slovanov Avstrije. Ljubljana. Prevod 1981, Slovenska Matica. Ljubljana. ??

Longyka, I. 1999: Prikazi slovenskega ozemlja. Ilustrirana zgodovina Slovencev. Ljubljana.

Lovrić, P. 1983: Kartografska repordukcija. Zagreb.

Lovrić, P. 1988: Pregled razvoja kartografije. Opća kartografija. Zagreb.

Markovič, M. 1993: Descriptio Croatiae. Hrvatske zemlje na geografskim kartama od najstarijih vremena do pojave prvih topografskih karata. Zagreb

Mihevc, B. 1998: Slovenija na starejših zemljevidih. Geografski atlas Slovenije. Ljubljana.

Orožen, F. 1901: Nekoliko o zemljevidih slovenskih pokrajin v prejšnjem in sedanjem času. Zbornik znanstvenih in poučnih spisov. Ljubljana.

Perko, D. 2005: Zemljevid in atlas, kartografija in geografija. Atlant. Ljubljana.

Peterca, M., Radošević, N., Milisavljević, S. 1974: Kartografija. Beograd.

Raisz, E. 1948: The history of maps. General cartography, second edition. New York.

Rajšp, V. 1994: Spremna beseda. Slovensko ozemlje na vojaškem zemljevidu iz druge polovice 18. stoletja. Ljubljana.

Reisp, B. 1995: Florjančičev veliki zemljevid Kranjske iz leta 1744. Monumenta Slovenica 6. Ljubljana.

Rojc, B. 1990: Kartografsko delo Janeza Vajkarda Valvasorja. Valvasorjev zbornik, str. 165-180. Ljubljana.

Sindik, I. 1931: Stare karte Jugoslovenskih zemalja. Atlas Geografskog društva 6. Beograd

Sindik, I. 1932: Stare karte Jugoslovenskih zemalja. Atlas Geografskog društva 8. Beograd

Slovenci v svetu. 1986: NUK. Katalog razstave. Ljubljana. 33 str.

Slukan Altić, M. 2003: Povijesna kartografija - kartografski izvori u povijesnim znanostima. Zagreb.

Stopar, I. 2006: Zemljevid vojvodine Štajerske. Topographia Ducatus Stiriae. Maribor.

Škrivanić, G. A. 1979: Monumenta cartographica Jugoslaviae II, Historical institute, Monographies 18. Narodna knjiga. Beograd.

Vrišer, I. 1998: Uvod v geografijo. Ljubljana.

Vobovnik Avsenak, M. 1982: Kartografsko in slikovno gradivo. Zakladi narodne in univerzitetne knjižnice. Ljubljana.

Wawrik, F., Zeilinger, E. 1989: Austria picta: Österreich auf alten Karten und Ansichten. Graz

Žagar, M. 1973: Razgledi: Blaž Kocen. Geografski vestnik. Ljubljana. 



\section{Kartografske upodobitve Slovenije skozi čas}

UDK: $912.43(497.4)(091)$

528.9(497.4)(091)

COBISS: 1.02

IZVLEČEK: Ozemlje Slovenije je prikazano že na najstarejših evropskih zemljevidih. Položaj Slovenije na stičišču različnih naravnogeografskih enot in političnih tvorb sta vplivala na njen prometni in mejni položaj. Zato se območje Slovenije na zemljevidih dolga stoletja prikazuje nenatančno in kot del tujih državnih enot. Z razvojem kartografske stroke in uveljavitvijo kartografije na naših tleh, pa se v 16. stoletju, zlasti pa od 17. stoletja dalje prek domačih in tujih posameznikov slovenski prostor enakovredno prikazuje na zemljevidih tistega časa. Sprva prevladujejo zemljevidi posameznih slovenskih pokrajin, od srede 19. stoletja naprej pa so pogostejši prikazi celotnega slovenskega ozemlja. Kartografska dela tako postanejo tudi način izražanja narodovih zahtev in želja.

KLJUČNE BESEDE: geografija, historična kartografija, zemljevidi, Slovenija

Uredništvo je prejelo prispevek 5. oktobra 2006.

NASLOV:

Primož Gašperič, profesor zgodovine in geografije

Geografski inštitut Antona Melika

Znanstvenoraziskovalni center Slovenske akademije znanosti in umetnosti

Gosposka ulica 13, SI - 1000 Ljubljana, Slovenija

E-pošta: primoz.gasperic@zrc-sazu.si

\section{Vsebina}

1 Uvod 263

$2 \quad$ Pregled zemljevidov po obdobjih 263

2.1 Antika 263

2.2 Srednji vek 264

2.3 Novi vek 265

3 Sklep 272

4 Literatura 273 


\section{Uvod}

Slovenci smo lahko upravičeno ponosni, saj se kljub številčni majhnosti in velikostno manjšemu nacionalnemu ozemlju, z vidika naše kartografske dediščine uvrščamo med bogatejše narode. V zgodovini smo bili pod okriljem večjih narodov, različnih političnih tvorb. Geografska lega in nacionalna pripadnost sta nas spodbujali k ohranjanju stikov s srednjeevropskimi in jugovzhodnimi kulturnimi tokovi. Predvsem vpetost $\mathrm{v}$ habsburško državno tvorbo je skoraj pol tisočletja omogočala neposredne stike s sosednjimi narodi, kar je pripomoglo k izpopolnjevanju kartografskih tehnik, metod in celotnega kartografskega razvoja na naših tleh. Nemško govoreči kartografi so veljali za dobre in cenjene ustvarjalce zemljevidov od začetkov sodobnejše kartografije novega veka. Skupaj z nizozemskimi, francoskimi in italijanskimi kartografi so tvorili gonilno silo evropske kartografije.

Slovenski prostor začnejo tuji kartografi pogosteje upodabljati na zemljevidih v začetku 16. stoletja, bolj natančno pa od druge polovice 17. stoletja naprej. Vzroki za to so predvsem želje posameznih držav po prikazu lastnih ozemelj, vojaške zahteve, razmah tiskarskih tehnik in nenazadnje potreba po zemljevidih, ki so prikazovali tudi dežele novo odkritega sveta. Zaradi obrobne politične vloge slovenskega prostora in nepoznavanja ozemlja, je le-ta sprva na zemljevidih največkrat vrisan netočno in površno.

To se spremeni v 17. stoletju, ko domači in na našem ozemlju živeči tuji ustvarjalci z lastnim terenskim delom izmerijo in opišejo posamezne dele slovenskega prostora. Najpogostejši so zemljevidi slovenskih dežel Kranjske, Stajerske, Istre in Koroške. Zaradi gospodarskih potreb so v tem času nastali tudi številni prikazi manjših območij, največkrat v obliki zelo podrobnih in slikovitih tematskih zemljevidov (rudnikov, cest).

Z narodnim preporodom v drugi polovici 19. stoletja začnejo izhajati zemljevidi etničnega slovenskega ozemlja. Avstrijska kartografija, ki je v tem obdobju segala v sam kartografski svetovni vrh, je tudi v Sloveniji pustila močan pečat. Slovenija je sprva kot del južnoslovanskih državnih tvorb, nato pa kot samostojna država tudi v 20. stoletju ohranila in razvijala kartografsko znanost v skladu z najsodobnejšimi svetovnimi standardi.

V članku želimo predstaviti kartografska dela, ki so nastala v različnih obdobjih zgodovine in prikazujejo ozemlje današnje Republike Slovenije do začetka 20. stoletja. Iz zemljevidov lahko razberemo družbeni in gospodarski razvoj območja v določenem času, pa tudi stopnjo razvoja kartografije kot vede. V nekaj primerih so omenjena tudi kartografska dela, ki v večjem ali manjšem merilu le delno prikazujejo naše ozemlje, so pa zanimiva zaradi svojih zgodovinskih, tehničnih in drugih lastnosti.

Namen članka je tudi predstaviti nekatere temeljne lastnosti zemljevidov, jih postaviti v zgodovinsko obdobje ter tako prikazati časovni razvoj kartografskih upodobitev naših krajev.

\section{Pregled zemljevidov po obdobjih}

\subsection{Antika}

V prazgodovini je bilo risanje »zemljevidov« vrsta umetniškega izražanja posameznikov ali skupin, ki ni imelo veliko skupnega s kasnejšim, predvsem pa sedanjim kartografskim delom. Takratni »zemljevidi« so bile preproste slike nekega objekta, posestva ali dela naravnega okolja, v katerem je avtor živel. Slike so bile narisane, spraskane ali vrezane na različne naravne materiale, kot so les, kosti, glina, kamen oziroma stene jam. Večina se jih zaradi podnebnih razmer ter neobstojnosti materiala in barv ni ohranila.

Danes znani najstarejši »zemljevid «, ki je bil vrezan v mamutov okel, in so ga našli leta 1966 v Ukrajini, datira v 12. tisočletje pr. n. št. (Perko 2005). Vendar ni dvoma, da so predhodniki zemljevidov nastajali že davno prej. V tisočletjih pred Kristusom so civilizacije kot so babilonska, egipčanska, sumerska, feničanska, kitajska in indijska razvile matematično in filozofsko vedenje, s katerim so si pomagale pri dojemanju in risanju njim znanega sveta. Žal se je do danes ohranilo zelo malo kartografskih izdelkov tistega časa.

Razvoj kartografije se na evropskih tleh začne v antiki. Prvo znanstveno osnovo risanju zemljevidov in kartografiji kot vedi so dali stari Grki. Mnogi znani učenjaki tistega časa so se ukvarjali z ugotavljanjem oblike zemlje, njeno velikostjo in risanjem le-te.

Anaksimander je v 6. stol. pr. n. št. sestavil prvo karto takrat poznanega sveta, ki se ni ohranila. Eratosten je v 3. stol. pr. n. št. zelo natančno izračunal dolžino poldnevnika in na podlagi svojih ugotovitev 
naredil karto sveta. Kot prvi je na zemljevid narisal popolnejšo geografsko mrežo. Takoj za Dikearhom, ki je na karti sveta prvi podal poldnevnik in vzporednik, je Eratosten na svoj zemljevid vnesel sedem poldnevnikov in sedem med seboj enako oddaljenih vzporednikov. Okoli leta 100 je Marinus iz Tira, ki naj bi bil oče matematične geografije, naredil karto sveta, ki se ni ohranila. Sestavil jo je na podlagi točk, za katere je bila znana geografska širina, geografsko dolžino pa je izračunal s pomočjo itinerarijev (popisov potovanj - potopisov). Klavdij Ptolemaj velja za najbolj znanega antičnega geografa. Živel je v 2. stoletju in izdal delo Geografija ter zemljevid takrat znanega sveta, ki pa se v originalu ni ohranil. Po zaslugi Arabcev, se je njegovo pisno delo skoraj v celoti ohranilo, njegov zemljevid sveta pa so v najrazličnejših izvedbah in predelavah izdajali še v novem veku (Vrišer 1998).

Antična kartografija je po Ptolemaju začela nazadovati. V času starega Rima so se kartografski izdelki podredili praktičnim zahtevam trgovine, vojske in prometa. Rezultat takšnega dojemanja so bili grafični itinerariji, zemljevidi, ki prikazujejo kraje in natančne razdalje med njimi, vse ostalo na njih pa je bilo manjšega pomena in zato tudi zelo posplošeno.

Iz antike ni ohranjeno veliko kartografskega gradiva. Vzrok za to je majhno število izdelanih zemljevidov ter dolgo obdobje, v katerem se zaradi različnih vzrokov le-ti niso ohranili. Slovenski prostor je bil v tem zgodnjem kartografskem obdobju prikazan le kot del širšega območja, zato so nam delno lahko $\mathrm{v}$ pomoč le rimski itinerariji.

- Delo Geographike hyphegesis (Geografija) Klavdija Ptolemaja iz 2. stoletja sestavlja osem knjig. Prva obravnava splošne principe kartografije in metode kartografske projekcije, naslednjih šest knjig vsebuje navodila za sestavljanje kart in podatke o geografski legi krajev, rek in podobno. V osmi knjigi je zbranih sedemindvajset kart takrat znanega sveta: pregledna karta sveta, deset kart Evrope, dvanajst kart Azije in štiri karte Afrike (Slovenci ... 1986). Ptolemajevi zemljevidi se kot že omenjeno niso ohranili, so bili pa osnova številnim kasnejšim kartografskim upodobitvam v začetku novega veka.

- Itinerarij Hierosolymitanum ali Burdigalense oziroma Jeruzalemski potopis je najstarejši znani opis poti nekega kristjana v Sveto deželo. Napisal ga je anonimni romar v letih 333 in 334, doma verjetno iz Burdigala (današnji Bordeaux). Itinerarij je popis krajev s krajšimi komentarji, ki jih je avtor zapisal na svoji poti. Romanje je začel v Burdigalu v današnji Franciji in pot nadaljeval preko ozemlja Severne Italije, Slovenije, Balkanskega polotoka do Jeruzalema in nazaj preko Italijanskega polotoka (internet 4).

- Tabula Peutingeriana je srednjeveška kopija Castorijevega cestnega zemljevida rimskega imperija iz 1. stoletja. Zemljevid je dobil ime po augsburškem starinarju, ki ga je imel v lasti od leta 1508 (Goss 1993). Zemljevid je sestavljen iz enajst odsekov (verjetno jih je bilo v izvirniku dvanajst) širine 34 centimetrov in dolžine 6,8 metra. Na zemljevidu so poudarjene predvsem ceste v rdeči barvi in kraji, z možnostjo nastanitve. Relief označujejo verige svetlo rjavih gričev, reke so vijugaste črte v zeleni barvi. Večji, obzidani kraji so označeni s stavbami in obzidjem, manjši pa s stolpi ali samo z imenom kraja. Izjeme so Rim, Konstantinopel in Antiohija, ki so zaradi svoje pomembnosti prikazani s podobo božanstva (Goss 1993). Poleg cest in poti so vpisane tudi razdalje med kraji z dolžinami v rimskih miljah (Mihevc 1998).

\subsection{Srednji vek}

Po razpadu zahodnega rimskega cesarstva, preseljevanju ljudstev in zatonu antične kulture je nastopilo obdobje, imenovano srednji vek. Njegova pregovorna »temačnost« je odraz kulturnega nazadovanja, ki so ga s svojim delovanjem in izdanimi deli nekoliko omilili Arabci. Kartografija v obdobju starega Rima kvalitativno ne napreduje, vendar grška spoznanja vzamejo za svoja in jih ali prevzamejo ali prilagodijo svojim potrebam. V srednjem veku se to znanje pozabi, kasneje se mu pogosto nasprotuje in se ga celo zavrača. Krščanska Evropa se začne kulturno obnavljati šele ob odkrivanju antike ter ob stikih s sosednjimi narodi (Arabci). Na dolgotrajno in mnogokrat težavno sprejemanje antičnih, arabskih in drugih spoznanj zelo vpliva krščanska Cerkev. S pomočjo samostanov, svoje organizacije in močnega vpliva, ki ga ima, postane sito med postopnim odkrivanjem drugih spoznanj in kultur ter krščanskimi nazori in dogmami.

V kartografiji se uveljavi krščansko gledanje na svet. Zemlja, ki ima okroglo, ovalno ali štirioglato obliko je plavajoča plošča, ki jo obdaja morje. Največkrat so avtorji zemljevidov menihi iz različnih samostanov, zato imenujemo to dobo tudi obdobje samostanske ali meniške kartografije.

Med zemljevidi prevladujejo tako imenovane T-O karte, ki vsebujejo rimsko zasnovo okroglega sveta (lat.: orbis terrarum). Svet je razdeljen na tri dele: v zgornji polovici krogle leži Azija, v spodnji levi polovici 
leži Evropa, v spodnji desni pa Afrika. Mejo med Evropo in Afriko, v smeri sever-jug, predstavlja Sredozemsko morje, mejo med Azijo in spodnjo polovico krogle, v smeri vzhod-zahod, pa reka Don. Obe ločnici med celinami oblikujeta črko T, njuno stičišče pa sovpada z lego Svete dežele. Obdajajoče morje predstavlja črko O (Fridl 1999). Od tod tudi poimenovanje T-O karte. Omenjene karte poleg estetskega vpliva niso bistveno vplivale na razvoj kartografije. Poleg njih moramo v poznem srednjeveškem obdobju omeniti še tako imenovane kompasne karte in karte arabskih avtorjev.

V 12. stoletju se je v Evropi začel počasen a vztrajen proces kartografske »renesanse«, ki je temeljil na iznajdbi kompasa, portulanih in Ptolomajevih delih. Povečale so se potrebe po političnih in gospodarskih stikih. Kompasne ali portulanske karte so za tisti čas zelo točni zemljevidi, ki natančno prikazujejo obalno črto, pristanišča in kompasne smeri plovbe po morju. Arabska kartografija je v srednjem veku dosegla visoko stopnjo razvoja, ki je temeljila na antičnem izročilu, lastnih meritvah, dopolnitvah in ugotovitvah. Zaradi jezikovnih, verskih in političnih razlogov je imela majhen vpliv na evropsko kartografijo.

- Leta 1119 je kartograf Guido (Guido Pisanus) narisal zemljevid zahodnega Rimskega cesarstva. Zemljevid je zelo poenostavljen, zaradi orientiranosti proti vzhodu in z Rimom v središču spominja na T-O karto sveta. Meje posamezne provinc so prikazane $\mathrm{z}$ dvema vzporednima črtama, na območju današnje Slovenije se nahaja napis »Carantanos« (Kärnten 1984). Zemljevid verjetno predstavlja prvo kartografsko delo s poimenovanjem slovenskega ozemlja.

- Leta 1154 je izšel tako imenovani Al-Idrisijev atlas. Gre za karto sveta, sestavljeno iz sedemdesetih listov, orientiranih proti jugu in $\mathrm{v}$ barvah. Njen avtor je mavrski kartograf Al Idrisi, izdelal jo je v Palermu. Merila je verjetno 3,5 ×1,5 metra, narejena pa je bil na osnovi klimatskih pasov (internet 5). Avtor je s tem delom dokaj uspešno posredoval arabske geografske izkušnje na sredozemska tla. Po zaslugi arabskih mornarjev in trgovcev imajo obale na karti že pravilnejše oblike, gorovja pa so narisana v nizih krtin.

- Okrog leta 1235 je bila v samostanu v Ebstorfu naslikana tako imenovana Ebstorfska karta. Gre za barvno stensko podobo v benediktinskem samostanu, ki so jo narisali menihi iz Saške. Velja za največjo znano karto srednjega veka, saj je merila 3,58 ×3,56 metra. Orientirana je proti vzhodu z Jeruzalemom v sredini. Ker je bila med drugo svetovno vojno uničena, obstajajo le njene fotografije in reprodukcije (Slovenci ... 1986). Na karti je Koroška verjetno prvič poimenovana kot »Carinthia« (Kärnten 1984).

- Leta 1439 je bila izdelana rokopisna karta srednje Evrope, leta 1491 pa odtisnjena v lesorezni tehniki. Njen avtor je kardinal Nicolaus Cusanus, ki je bil škof v Brixnu. Karta, katere original se ni ohranil, je ostala znana zaradi kasnejših rokopisnih predelav in bakroreznih odtisov (Slovenci ... 1986; Marković 1993). Avtor se je zgledoval po Ptolemajevih zemljevidih, orientirana je proti severu, ozemlje Slovenije je prikazano na južnem delu karte.

- Leta 1459 je menih Fra Mauro izdelal veliko stensko karto sveta, ki velja za vrhunski dosežek srednjeveške kartografije. Je okrogle oblike, premera približno 1,95 metra, bogatejša in podrobneje narisana kot ostale karte tistega časa. Afrika in Azija se ne stikata na jugu in tako ne zapirata Indijskega oceana (Goss 1993). Na karti so označena tudi mesta in imena na območju današnje Slovenije.

- Erhard Etzlaub je avtor dveh romarskih zemljevidov. Leta 1492 je izšel Daß ist der Rom Weg von meylen zu meylen mit puncten verzeychnet von eyner stat zu der andern durch deutzsche lantt, ki je obsegal manjše območje, kot zemljevid Das sein dy lantstrassen durch das Romisch reych von einem Kunigreych $z w$ dem andern dy an Tewtsche land stossen von meilen mit puncten verzeichnet iz leta 1501. Zaradi praktičnosti uporabe, sta bila zemljevida orientirana proti jugu (lažja uporaba Etzlaubovega kompasa, cilj romanja je Rim, ki je na zemljevidu zgoraj - pred romarjem). Gorovja in hribovja so označena s širšimi osenčenimi pasovi, kraji pa s krogcem in imenom. Ceste so prikazane z linijo pikic, od katerih vsaka izmed njih predstavlja razdaljo ene nemške milje. Pri prvem zemljevidu so bile označene le glavne poti, ki so vodile proti Rimu, na drugem zemljevidu pa je gostota poti večja (Kärnten 1984).

- Leta 1493 je humanist in zgodovinar Hartmann Schedel objavil delo Nûrnberška kronika, Delo vključuje tudi karto večjega dela Evrope, natisnjeno v lesorezni tehniki. Avtorja karte sta Wilhelm Pleydenwurff in Michael Wolgemot (Kozličić 1995). Karta je orientirana proti severu, na njenem južnem delu je upodobljeno območje Slovenije in del Jadranskega morja. Reke so narisane v obliki trakov, gorovja so upodobljena s krtinami, med njimi pa so vpisana imena le nekaterih večjih krajev.

\subsection{Novi vek}

Že v obdobju srednjega veka je bilo težko govoriti o enotnem razvoju in dosežkih na področju kartografije. Kljub temu, da je meja med srednjim vekom in novim vekom okoli leta 1500, so se začetki kartografske- 
ga preporoda začeli že v 12. stoletju. Vzrokov za te spremembe je več: uporaba kompasa, osvajalni vojaški pohodi, gospodarski in kulturni stiki, ponovno odkrivanje antičnih kartografskih del in delno tudi arabska kartografija, ki je v tem obdobju dosegla svoj višek.

Svoj razmah je kartografija dosegla v dobi odkritij, ki se deloma ujema s časovno delitvijo na srednji in novi vek. Številna potovanja po kopnem predvsem pa po morju (odprave Henrika Pomorščaka) so znanilec sprememb pri odkrivanju nepoznanega sveta. Odprave Diaza, Kolumba, da Game, Cabota in kasnejših raziskovalcev so se vrnile z novimi meritvami, upodobitvami in spoznanji, ki so povzročila željo in tudi nujo po kvalitetnejšem kartografskem prikazovanju Zemlje. Za dosego tega pa je bilo potrebno izboljšati tehniko izdelave zemljevidov. Z Guttenbergovim izumom tiska s premičnimi črkami, je tiskarska tehnika v 15. stoletju doživela preporod in se skupaj s kartografsko tehniko razvija vse do danes. Novi vek zaznamuje prav hiter razvoj obeh strok. Skozi vseh pet stoletij novega veka je želja vsakega kartografa, ustvarjalca zemljevida, da se s svojo karto čim bolj približa resnični podobi zemeljskega površja.

Na začetku novega veka so na razvoj kartografije vplivala raziskovanja in osvajanja posameznih velesil. V prvi polovici 16. stoletja so imeli vodilno vlogo pri razvoju kartografije Italijani. Benetke so bile središče razvoja in raziskovalnega dela. Dela G. Gastaldija in kasneje V. M. Coronellija predstavljajo vrh italijanske kartografije tistega časa. Zelo kakovostna kartografska dela so izdelovali tudi Španci in Portugalci. V drugi polovici 16. stoletja so pobudo na kartografskem področju prevzeli Nizozemci. A. Ortelius, G. Kremer Mercator in kasneje W. J. Blaeu so s svojimi zemljevidi in atlasi zaznamovali nadaljnji razvoj kartografske dejavnosti. Območje današnje Slovenije prikazujejo vsi pomembnejši atlasi te dobe, na primer Atlas maior sive cosmographia Blaviana W. J. Blaeuja, Atlante Veneto V. M. Coronellija (Korošec 1978). V 16. stoletju so bili zelo dejavni tudi angleški kartografi ter kartografi iz osrednje, predvsem nemško govoreče Evrope, zlasti S. Münster in W. Lazius.

- Letnico 1525 nosi karta Istre avtorja Pietra Coppa. Velik del svojega življenja je preživel v Izoli in je prvi kartograf s tega dela Jadrana, ki je izdal tiskano zbirko zemljevidov (Kozličić 1995). Dodal jo je rokopisnemu piranskemu kodeksu De summa totius orbis, ki je povzetek njegovega obsežnega dela De toto orbe iz leta 1520.

Karta Istre prikazuje območje Slovenije, Istre in Dalmacije. Vsebuje okoli dvesto petdeset toponimov. Otoki, obale, zalivi in rečna mreža so prikazani dokaj natančno, naselja v notranjosti polotoka pa so narisana v nesorazmerju. Vzrok za razliko v natančnosti je Coppovo različno poznavanje posameznih delov polotoka (Marković 1993). Kartografsko gledano je karta za tisti čas zelo kvalitetno narejena in prekaša kasnejšo Münstrovo Descriptio totius Illyridis ter velja za najkvalitetnejšo kartografsko upodobitev Istrskega polotoka do sredine 18. stoletja. Skupaj s kodeksom jo hranijo v Pomorskem muzeju "Sergej Mašera« v Piranu (Mihevc 1998; Longyka 1999).

- Leta 1542 je bila v lesorezni tehniki izdelana karta Descriptio totius Illyridis Sebastiana Münstra. V originalu meri 34,0 $\times 25,2$ centimetrov. Karta je bila dodana zbirki Ptolomajevih antičnih kart in je prvič omenjena v Münstrovi tretji dopolnjeni izdaji Ptolemajeve Geografije (prva izdaja Münstrove Ptolemajeve Geografije je izšla leta 1540). Prikazuje območje Slovenije, dela Hrvaške in zahodno Bosno. Orientirana je proti jugu, gorovja so prikazana s holmi, poleg imen večjih krajev so navedena še imena gradov in samostanov. Najbolj izstopa gozdni pas v obliki drevoreda, ki ponazarja sklenjeno gozdnato hribovje od Trnovskega gozda, prek Hrušice, Snežnika, Gorskega Kotarja do Bosne. Nazorno so vidne podobnosti s Ptolomajevimi zemljevidi (Bohinec 1969; Mihevc 1998).

- Augustin Hirschvogel je zadnjih nekaj let svojega življenja (do leta 1553) pripravljal kasneje poimenovan zemljevid Ogrske, ki je bil natisnjen šele leta 1565. Gre za eno prvih vojnih kart na avstrijskem ozemlju (Korošec 1978). Original ni ohranjen, znana pa je zaradi številnih ponatisov, predvsem po Orteliusovi priredbi v njegovem delu Theatrum Orbis Terrarum. Verjetno je bil zemljevid osnova številnim kasnejšim zemljevidom tega območja. (Longyka 1999). Nekateri izmed njih so omenjeni v nadaljevanju.

- Leta 1560 je bila izdana karta Geografia particolare d'una gran parte dell'Europa, nuonamete descritta cō i confini suoi, e prima uerso leuate e il meridian odi constantinopoli, e da ponetē il meridiano dela magca cita di Venetia etc. avtorja Giacoma Gastaldija. Karta meri 83,5 $\times 103,5$ centimetrov in je narejena v bakrorezni tehniki. Prikazuje območje Balkanskega polotoka, obalna območja so prikazana bolj natančno kot celinska, podobna je njegovi karti Ogrske iz leta 1546 (Marković 1993). Relief je prikazan s krtinami, ki so razporejene šablonsko in ne prikazujejo realne podobe površja. Nekateri toponimi so popačeni do nerazpoznavnosti (Dörflinger 1977). 
- Leta 1561 je izšla zbirka enajstih kart z naslovom Typi chorographici Provinciarum Austriae dunajčana Wolfganga Laziusa. Zemljevidi so sprva izhajali posamezno, nato pa so bili izdani kot celota in skupaj predstavljajo prvo zbirko tako imenovanih specialnih avstrijskih kart. Slovensko ozemlje je prikazano na štirih kartah, ki imajo obliko ovala, katerega drži dvoglavi avstrijski orel. Ena od omenjenih kart ima naslov Ducatus Carniolae et Histriae una cum Marcha Windorum (Vojvodina Kranjska in Istra s Slovensko marko) in je prvi znan samostojni prikaz vojvodine Kranjske. Lazius je bil zgodovinar in je v zemljevidih videl način, kako z ilustriranimi podobami prikazati dežele. Zato je na kartah poudarjal zgodovinske značilnosti, zanemarjal pa je kartografsko točnost prikaza. Zemljevide je tudi sam izdeloval, kar je še dodatno prispevalo k njihovi nenatančnosti (Slovenci ... 1986; Longyka 1999). Laziusove karte so podatkovno sorazmerno podrobne, vendar polne napak: nimajo matematično-geografske podlage, so brez stopinjske mreže, brez merila, naselja so pogosto na napačnem kraju, tok rek poteka napačno, gorovja so upodobljena le približno. Karte so kljub vsemu pomemben vir krajevnih imen za ozemlje današnje Slovenije v 16. stoletju. Imele so velik vpliv na tuje kartografe, ki so prevzeli poleg podrobnih podatkov tudi številne napake.

- Leta 1563 je beneški kartograf Giovani Francesco Camocio narisal zemljevid, ki ga je kasneje Ferando Bertelli predelal in ga leta 1565 izdal pod naslovom Nova discrittione della Dalmatia et Crovatia. Karta prikazuje Slovenijo, Istro, del Dalmacije, Slavonijo in del Bosne. (Slovenci ... 1986). Bertellijev zemljevid se od originala razlikuje le po načinu izdelave. Grafični prikaz je nežnejši, kar se vidi pri prikazu reliefa, morske obale in rekah, ki so narisane s tankima linijama (Marković 1993).

- Leta 1569 je nastala karta Ducatus Carniolae una cum Marchia Windorum (Vojodina Kranjska s Slovensko marko) benečana Bologninusa Zalteriousa (Orožen 1901). Narejena je v bakrorezni tehniki, velikosti $32,2 \times 42,3$ centimetrov. Avtor se je pri njeni izdelavi zgledoval po Laziusovi karti Ducatus Carniolae et Histriae una cum Marcha Windorum. Za karto je značilna beneški grafika in podatki iz avstrijskih kart tistega časa (Marković 1993).

- Leta 1570 je Abraham Ortelius v prvo izdajo atlasa Theatrum Orbis Terrarum vključil karto Schlavoniae, Croatiae, Carniae, Istriae, Bosniae, finitimarumque regionum nova descriptio (Novi prikaz Slavonije, Hrvaške, Kranjske, Istre, Bosne in sosednjih pokrajin). Gre za predelani Hirschvoglov zemljevid Ogrske, ki ga je Ortelius v pomanjšani obliki vključil v svojo zbirko. Karta prikazuje v zgornjem delu ozemlje med Osojskim jezerom in srednjo Donavo, v spodnjem delu pa območje med Jadranskim morjem in Sarajevom ter Višegradom. Jadranska obala in otoki so še zelo podobni Ptolomajevim zemljevidom, notranjost pa je že točneje prikazana, saj jo je Hirschvogel bolje poznal. Sava teče od zahoda naravnost proti vzhodu, ima pa bolj pravilno vrisane in poimenovane pritoke kot ostale karte tistega časa. Cerkniško jezero je pravilne velikosti, gorovja so risana s hribčki, naselja so prikazana z mesti, samostani, cerkvami in gradovi, njihova lega in razdalje med njimi pa so mnogokrat napačne. Leta 1573 je v tretji izdaji povzel še karte Histriae tabula (Istra in zaledje) Pietra Coppa ter Carinthiae ducatus, et Goritiae palatinatus (Koroška in Goriška) in Goritiae, Karstii, Chaczeolae, Carniolae, Histriae, et Windorum marchae descrip. (Opis Goriške, Krasa, Kočevske, Kranjske, Istre in Slovenske marke) Wolfganga Laziusa. Slednja meri v originalu $23,2 \times 31,0$ centimetrov. Karta po obsegu prikazanega območja sovpada z Laziusovim zemljevidom, le skrajni del Istre je povzet od drugod. Velik pomen dajejo zemljevidu mnoga slovenska zemljepisna imena. Žal pa je, tako kot na ostalih Laziusovih kartah oziroma kartah, ki so povzete po njegovih kartah, veliko napak zaradi napačne lege krajev, izmišljenih ter prirejenih podatkov (Slovenci... 1986).

- Leta 1572 je nastala karta Illyricum avtorja Ioanesa Sambucusa (Jänuos Zsämboky) v približnem merilu $1: 1.200 .000$ in velikosti 46,6×35,6 centimetrov. Gre za dopolnjeno Hirschvoglovo karto Ogrske. Zemljevid je leta 1573 Ortelius objavil $\mathrm{v}$ drugi izdaji Theatrum orbis terrarum. V mnogih primerih (na primer Istra) so območja že točneje narisana vendar se še vedno oblikovno in podatkovno pozna vpliv Ptolomajevih kart. Na kartografskem področju je bil Sambucus Laziusov naslednik. Zbiral je stare zapiske in zemljevide, ki jih je predelal in popravil ter na novo izdal (Bohinec 1969, Marković 1993).

- Leta 1589 je izšla karta Karstia, Carniola, Histria et Windorum Marchia (Kras, Kranjska, Istra in Slovenska marka) avtorja Gerarda Kremerja Mercatorja. Izšla je v zbirki večjega števila kart, v originalu pa meri 38,0 × 49,0 centimetrov (Marković 1993). Mercator je podatke za območje Slovenije povzel po Orteliusu, ta pa po Laziusovih zemljevidih (na primer karta Ducatus Carniolae et Histriae una cum Marcha Windorum). Posledica so bile številne netočnosti. Lep primer je neobstoječa Planinska reka (Alben fluvius), 
ki izvira vzhodno od Logatca in se izliva v morje pri Kopru. Gorovja so prikazana s krtinami, gozdovi s skupinami dreves, naselja so že označena s krožci.

- Leta 1612 je nastal zemljevid Koroške (Archiducatus Carinthiae fertilissimi Carantania olimet Carnia, dicti, ex diligenti omnivum Locorum Perlustratione et Dimensione, noua, vera, et Exactissima Geographia avtorja Israela Holzwurma. Leta 1616 je bil zemljevid ponovno izdan (prvi velja za izgubljenega), vendar v dvakrat manjšem merilu (približno $1: 593.600$ ). Kljub njegovi majhnosti, je natančen in ima veliko topografskih podatkov. Presenetljivo dobro je prikazano vodovje, hribi so krtine, ki s svojo velikostjo ponazarjajo višino. Ceste niso označene, so pa mostovi preko reke Drave. Meje pokrajin so označene s pikčastimi linijami. Kraji in posamezna območja (na primer območja $z$ vinogradi, toplice) so prikazani s petnajstimi različnimi znaki, rudniki pa s svojimi oznakami (Kärnten 1984).

- Od leta 1635 naprej je Nizozemec Willem Janszoon Blaeu s sinovoma Johannesom in Corneliusom izdajal Theatrum Orbis Terrarum, sive Atlas Novus. Njihova dela so bila najprej nadaljevanje in dopolnitev Orteliusovih in Mercatorjevih del, nato pa je atlas prerasel v samostojno delo. Tako kot ostala območja, je tudi Slovensko ozemlje prikazano na številnih zemljevidih, ki so povečini prirejeni po Orteliusovih in Mercatorjevih delih.

Izpeljanke Mercatorjevih zemljevidov, ki prikazujejo slovensko ozemlje, vsebujejo tudi atlasi Jodoca Hondiusa in Johannesa Janssoniusa. Družina Hondius je namreč podedovala Mercatorjeve tiskarske plošče in njegove zemljevide.

- Leta 1657 je Nicolas Sanson izdelal karto Hertzogthūber Steyer, Karnten, Krain \& c. Duchés de Stirie, Carinthie, Carniole (Vojvodina Štajerska, Koroška in Kranjska). Karta zajema območje med Gornjo Štajersko in Istro ter območje med Piavo in Blatnim jezerom. Stopinjska mreže še ni pravilna, vendar se upodobitev obale, gorovij in hidrografske mreže že približuje dejanskemu stanju. Za območje slovenskega ozemlja se pozna vpliv netočnosti Laziusovih zemljevidov (Bohinec 1969; Slovenci ... 1986). Sanson je najpomembnejši francoski kartograf v 17. stoletju, bil je kraljevi geograf Ludvika XIII. in XIV. S sinovi je izdelal veliko zemljevidov, ki jih je za izdajo pripravil francoski kartograf Charles Hubert Jaillot. Ti zemljevidi so bili izdani v atlasih, ki so bili po formatu zelo veliki.

- Leta 1678 je bila natisnjena karta Styriae Ducatus Fertilissimi Nova Geographica Descriptio (Najplodovitejše vojvodine Štajerske novi geografski opis) duhovnika, kartografa in topografa Georga Matthäusa Vischerja.

Zemljevid meri 123,5 × 135,5 centimetrov in je sestavljen je iz dvanajstih delov. Predloge zanje je v baker vrezal Andrej Trost. Zemljevid še ne podaja povsem resnične podobe pokrajine, vendar je zaradi posameznih izpopolnjenih elementov, zelo pomemben za napredek takratne kartografije. Zelo dobro so označeni rečna mreža in jezera, vzpetine so prikazane s hribčki in senčenjem, meje so zaradi avtorjevega nepoznavanja in političnih razmer posplošene. Karta prikazuje Štajersko, le izjemoma pa so označeni tudi kraji zunaj njenih meja. Kraji so označeni z različnimi kartografskimi znaki: mesta prikazuje tloris s prepoznavnimi značilnostmi, kot so utrdba, stolp ali grad. Manjša naselja so označena bolj površno. Razdalje, razmerja in projekcijska točnost so pogosto nepravilne, zato je merilo karte med 1:160.000 in $1: 172.800$. Na zemljevidu so narisani tudi gradovi in dvorci vseh pomembnejših gospostev, manj pomembna gospostva so označena s preprostimi topografskimi znaki ali pa sploh niso označena. Močan vizualni vtis dajejo zemljevidu bogate ilustracije in besedila, ki zapolnjujejo prazen prostor. Vse upodobitve prikazujejo dogodke in značilnosti, za katere je avtor menil, da jih je potrebno upodobiti. Na šestem listu je upodobil zmago avstrijske vojske nad turško leta 1664 pri Monoštru, ki jo upodablja boj nadangela Mihaela z zmajem. Na devetem listu, kjer sta legenda in merilo, so narisani številni merilni inštrumenti, ki jih je Vischer uporabljal pri izdelavi zemljevida. Poleg sta podobi angelov; eden drži avtorjevo podobo, drugi pa poskakujočo ribo, ki je prispodoba za avtorjev priimek (Vischer - ribič). Karta je narisana podobno kot zemljevidi Matthäusa Meriana (očeta in sina) ter Janeza Vajkarda Valvasorja (Korošec 1978; Stopar 2006).

Slika 1: Izsek zemljevida Styriae Ducatus Fertilissimi Nova Geographica Descriptio. Georg Matthäus Vischer, 1678. Zemljepisni muzej GIAM ZRC SAZU.

Glej angleški del prispevka.

- Leta 1689 je izšlo delo Slava vojvodine Kranjske polihistorja Janeza Vajkarda Valvasorja. V njem je objavljena Karta vojvodine Kranjske, katero je izdelal Valvasor sam. Karta je nekoliko predelana karta Carniolia, Karstia, Histria et Windorum Marchia, ki jo je avtor v dveh različicah izdelal leta 1681 za zgodovinsko 
delo Carniolia antiqua et nova Janeza Ludvika Schönlebna. Prva različica je karta tedanje Kranjske, druga pa zgodovinska karta. Osnova Valvasorjeve karte je prevzeta Merianova karta, ki je kopija Mercatorjeve Karstia, Carniola, Histria et Windorum Marchia. Valvasor je izboljšal zlasti upodobitev rečne mreže, korak nazaj pa je upodobitev Istre, kjer se ni zgledoval po Coppovi karti Istre (Longika 1999; Rojc 1990). Kljub stopinjski razdelitvi, je karta popačena, lega gorovij, ki so upodobljena z osenčenimi krtinami, je nenatančna, velikost Cerkniškega jezera je pravilna. Ne glede na napake, ki jih karta vsebuje, je bralcu Slave $\mathrm{v}$ pomoč pri orientaciji. Tedanjo Kranjsko deželo je Valvasor upodobil še na petih kartah upravnih enot, ki jih je vključil v drugo knjigo Slave.

- Leta 1690 je Giacomo Cantelli da Vignolla izdelal zemljevid Parte della Schiavonia, Overo Slavonia, agivnavi la Contea di Cillea, e Windisch Mark abitate da Popoli Slauini a Slavi ò descritta da Giacomo Cantelli da Vignola, ki prikazuje območje Slovenije vzhodno od črte Maribor-Litija-Cerkniško jezero, zahodno Slavonijo ter območje Hrvaške severno in južno od reke Kolpe. Cantelli je veliko podatkov za svoj zemljevid našel na karti Hrvaške iz leta 1673 avtorja Stjepana Glavača (Marković 1993). Relief je prikazan s šablonasto razporejenimi krtinami, nekatera gozdna območja so označena s skupino dreves. Zemljevid podaja dobro sliko porečja Drave in Save s svojimi pritoki, Cerkniško jezero je preveliko in pomaknjeno preveč proti vzhodu.

- V letih 1716-1724 (letnica ni znana) je nastala Tabula Ducatus Carnioliae, Vindorum Marchiae et Histriae (Karta vojvodine Kranjske s Slovensko marko in Istro) nürnberžana Johanna Baptista Homanna. Narejena je bil na podlagi Valvasorjevih podatkov (Lago 1996). Karta ne predstavlja tehničnega in vsebinskega napredka, je le grafično nekoliko izboljšana kopija Valvasorjeve Karte vojvodine Kranjske (Korošec 1978). Karti sta dodani veduta Ljubljane in karta Cerkniškega jezera.

Homann je izdelal več zemljevidov, ki delno prikazujejo tudi slovensko ozemlje. Njegov zemljevid Štajerske (Ducatus Stiriae Novissima) je pomanjšana priredba Vischerjevega dela, ki zajema slovenski del Štajerske in del Koroške. Karto vojvodine Kranjske je kasneje dopolnil in ponovno izdal Homannov učenec Matthias Seutter. Seutter je izdal tudi karto Carinthia Ducatus (zemljevid Koroške), ki poleg ostalih območij zajema tudi območja Kranjske do črte Bohinj-Radovljica-Kamnik (Slovenci ... 1986).

- Leta 1744 je izšla karta Ducatus Carnioliae tabula chorographica (Horografski zemljevid Vojvodine Kranjske) duhovnika Janeza Dizme Florjančiča. Gre za najkakovostnejši in najpopolnejši zemljevid Kranjske te dobe. Sestavlja ga dvanajst delov, ki se po velikosti nekoliko razlikujejo in merijo približno $45 \times 62$ centimetrov. Velikost celotnega zemljevida je približno $180 \times 188$ centimetrov. Zemljevid prikazuje na zahodu območje do Gorice in Gradišča ob Soči, na vzhodu do Žalca, Brežic in Karlovca, na severu do Trbiža, Železne Kaplje in Slovenj Gradca ter na jugu do Rovinja in Crikvenice na Hrvaškem. Na zemljevidu je uporabljena stopinjska mreža z začetnim meridianom, ki prečka otok Ferro na Kanarskih otokih. Merilo karte se na posameznih delih nekoliko razlikuje, vendar je razmerje približno $1: 100.000$. Zemljevid je narejen v perspektivni metodi, odlikuje ga izredna plastičnost prikazanega reliefa. Hribovja so narisana s krtinami, visokogorja pa z bolj koničastimi gorami in senčenjem. Hidrografska mreža je vrisana točneje kot pri predhodnikih, gozdove prikazujejo posamezna drevesa ali skupina dreves, območja vinogradov označuje narisana vinska trta. Na zemljevidu so navedena številna krajevna imena, mnogi kraji so označeni z različnimi znaki (na primer obzidje, cerkev) ki so opisani v legendi. Glavna pomanjkljivost zemljevida je cestno omrežje, saj mnoge ceste niso prikazane, pomembnejše pa so označene z enojno ali dvojno pikčasto črto (Reisp 1995; Longyka 1999).

Posebnost zemljevida sta v zgornji desni kot dodana veduta in načrt Ljubljane. Načrt je zelo natančen in je bil prvič objavljen. $V$ spodnjem desnem delu zemljevida naredi na uporabnika močan vtis baročno okrašena izvenokvirna vsebina z upodobljenimi prispodobami (na primer bogovi, vrč z vodo) in deželnimi značilnostmi (na primer putta, ki kujeta železo). Zemljevid je na bakrene plošče vrezal ljubljanski inženir in bakrorezec Abraham Kaltschmidt, ki se je podpisal tudi pod veduto Ljubljane. Zemljevid se uvršča med vrhunske izdelke takratne kartografije in zemljemerstva, pa tudi v sam takratni vrh grafične umetnosti.

Slika 2: Izsek zemljevida Ducatus Carnioliae tabula chorographica. Janez Dizma Florjančič, 1678. Zemljepisni muzej GIAM ZRC SAZU. Glej angleški del prispevka.

- Leta 1752 je Didier Robert de Vaugondy izdal zemljevid Partie Méridionale du Cercle d'Autriche, qui comprend La Basse Pertie du Duché de Stirie, Le Duché de Carinthie, divisé en haute et basse, Le Duché de Carniole, 
divise en haute, basse, moyenne et inter. Carniole, et l'Istrie Impériale. Zemljevid prikazuje južne dele takratne avstrijske ?države?. Nekatera območja (na primer Kras in Dalmacija) so narisana točneje kot na drugih zemljevidih tistega časa, iz česar lahko sklepamo, da se avtor ni zgledoval po Merkatorjevih zemljevidih, temveč kartografskih delih Giovannia Antonia Maginija, ki je prikazano območje bolje poznal (Lago 1996).

- Okoli leta 1760 je izšel Atlas novus, kjer je objavljen Conrad Tobias Lotterjev zemljevid Exactissima Ducatus Carnioliae, Vindorum Marchiae et Histriae delineatiocura et caelo Tob. Conr. Lotter. Zemljevidi v atlasu so površno izdelani in niso pomembni za napredek kartografije. Zemljevidi tudi niso zanesljivi, saj so meje med deželami in lokacije imen posameznih krajev ter ostale vsebine pogosto napačno vrisane (Orožen 1901). Lotter je bil zet Matthiasa Seutterja in je prevzel njegovo podjetje. S starih plošč je zbrisal Seutterjevo ime in ga zamenjal s svojim (Slovenci ... 1986).

- V letih 1763-1787 so izhajali tako imenovani Jožefinski vojaški zemljevidi. Vsaka sekcija je bila narejena v dveh primerkih, originalu in kopiji. Posamezni zemljevid meri $64 \times 42$ centimetrov in je izdelan v merilu $1: 28.800$. Konec 18 . stoletja so veljali za najpodrobnejši in najkakovostnejši kartografski izdelek. Narejeni so bili na osnovi prve geodetske izmere Habsburške monarhije. Bili so strogo varovan vojaški dokument, ki ni bil dostopen širši javnosti. Na zemljevidu so zelo podrobno navedena imena hribov, dolin in voda v deželnem jeziku. Ker je šlo za vojaške zemljevide, je na njih nazorno predstavljen teren. Natančno so vrisani hribi, vzpetine, njihove strmine in položne strani, gorska pobočja ter doline. Povsod so označili razširjenost gozdov, smer vodnih tokov, obdelovalna zemljišča in drugo. Natančno so predstavili kultiviranost pokrajine, ki jo izražajo vse vrste naselij, zgradbe, ceste in znamenja ob njih. Preglednost in nazornost so dosegli z natančnim risanjem in z uporabo različnih barv. Zanimivo je, da nahajališča naravnih bogastev (rude, sol) in fužin niso označili s simboli temveč z besedo. Status mest določa velikost in oblika črk, ponekod pa je dodan k imenu (Rajšp 1994).

- Leta 1778 je izšel prvi del knjige Baltazarja Hacqueta Oryctographia Carniolica oder physikalische Bescheibung des Herzogthums Krain, Istrien und zum Theil der benachbarten Länder, v kateri je objavljen tudi zemljevid brez naslova, poimenovan Krainska deschela (Zemljevid Kranjske). Kartografsko je zemljevid zastarel, njegova odlika pa so označena nahajališča kamnin in rudnin ter slovenski toponimi. Le izjemoma so navedena tudi nemška in latinska imena. Hacquetovi zemljevidi so prvi tematski geološki zemljevidi na Slovenskem (Longyka 1999).

- Leta 1782 je bila narejena Mappa Litho- Hydrographica Nationis Slavicae (Kamninsko-vodopisna karta slovanskih narodov). Njen avtor je Baltasar Hacquet, po njegovi predlogi pa jo je izdelal Leopold Lieber. To hidrološko-mineraloško karto je Hacquet leta 1784 vključil v tretji del svojega naravoslovnega dela Oryctographia Carniolica. Karta je narejena v merilu približno 1:420.000, je podolgovate oblike in prikazuje območje med porečjema Save in Drave. Alpe in Karavanke so upodobljene v perspektivni tehniki in senčenjem, Pohorje in koroški Dobrač pa s tako imenovanimi gosenicami. Porečji obeh rek in večji kraji so vrisani pravilno, posebnost so označena mineralna nahajališča. Imena krajev niso poimenovana v nemškem in italijanskem jeziku temveč so navedeni pretežno slovenski ali dvojezični izrazi (Wawrik in ostali 1989).

- V letih 1788 in 1791 sta izšla prvi in drugi del zgodovinskega dela Poskus zgodovine Kranjske in ostalih delov Južnih Slovanov dramatika Antona Tomaža Linharta. Kot priloga sta bila delu dodana dva zemljevida. Prvemu je bil dodan: Tabula Antiqua regionis inter Dravum Fluvium et mare Adriaticum (Zemljevid ozemlja med reko Dravo in Jadranskim morjem v antiki), drugemu pa: Conßpectus Karantaniae Bive Slavorum meridionalium ante Caroli M. imperium (Zemljevid Karantanije ali Južnih Slovanov pred cesarstvom Karla Velikega). Zemljevida prikazujeta enako območje v različnem zgodovinskem obdobju. Prvi zemljevid je večji, narisan v večjem merilu in kartografsko podrobnejši. Gorovje in hribovje je narisano s senčenimi krtinami, nižje vzpetine s črticami. Pri drugem zemljevidu je navedenih manj toponimov, ceste niso narisane, relief je šablonsko označen $\mathrm{z}$ rahlo senčenimi krtinami.

- Med letoma 1789 in 1797 so izhajali zemljevidi, ki so bili vključeni v Atlas von Innerösterreich (Die Provinz Inner-Oesterreich) avtorja Josepha Karla Kindermanna, Atlas prikazuje Notranjeavstrijske province: Vojvodino Štajersko, Koroško, Kranjsko, grofijo Goriško in Gradiščansko ter avstrijsko primorje. Sestavlja ga enajst zemljevidov merila $1: 255.000$ in pregledna karta notranjeavstrijskih dežel v merilu $1: 600.000$. Zemljevidi zelo plastično prikazujejo površje, označene so različne vrste naselij ter jezikovna meja med Slovenci in Nemci na Koroškem in Štajerskem (Korošec 1978; Wawrik in ostali 1989). 
- Leta 1812 je Joseph de Castro izdelal Carte von Inner=Oestrreich nach den neuesten astronomischen Ortsbestimungen und andern Hülfsquellen gezeichnet von Joseph de Castro. Zemljevid prikazuje Štajersko, Kranjsko in Istro. Sestavljen je iz šestih delov v merilu približno 1:290.000 (Dörflinger 1988). Naslov, legenda in merilo so napisani $\mathrm{v}$ nemškem in francoskem jeziku, toponimi na zemljevidu pa v nemškem jeziku.

Podoben Castrovemu zemljevidu in v večjem merilu izdelan je Charte von dem Königreiche Illyrien und dem Herzogthume Seyermark nach de Castros Charte von Inneroestreich entworfen von C. F. Weiland (Zemljevid Ilirskega kraljestva in Vojvodine Štajerske). Leta 1925 ga je izdelal saški geograf Carl Ferdinand Weiland. Zaradi gostote toponimov, je zemljevid težje berljiv.

- Leta 1832 je prvič izšla Karte von Herzogthume Krain (Karta Vojvodine Kranjske) vojaškega zemljemerca Gottfrieda Loschana. Njeno izdelavo je naročila Kmetijska družba za Kranjsko in predstavlja prvi zemljevid, ki je nastal dosledno na podlagi tedanjih generalštabnih deželnih kart (Korošec 1978). Narisana je v merilu $1: 288.000$. Relief je prikazan s preciznim črtkanjem, dobro izdelan in pregleden. Zaradi samo nemškega poimenovanja krajev, črno-bele barve in splošne vsebine, je karta zelo čitljiva v primerjavi s Freyerjevo Specialkarte. Leta 1844 je zemljevid izšel z enakim naslovom, vendar izboljšan in razširjen na območje vsega Ilirskega kraljestva (Orožen 1901; Longyka 1999). Ob strani zemljevida je dodan načrt Ljubljane in Trsta.

- Med letoma 1844 in 1846 je izšlo 16 listov Specialkarte des Herzogthums Krain (Posebna karta Vojvodine Kranjske) avtorja Henrika Karla Freyerja. Merilo karte, ki ima za osnovo avstrijsko generalštabno karto iz leta 1834, je $1: 113.500$. Natisnjena je bila v takrat novi tehniki, v petbarvnem kamnotisku. Relief je prikazan s senčenjem. Reke, potoki, ceste in kolovozi so vrisani zelo natančno, vendar ponekod manjkajo mostovi in brodišča. Freyerjeva zasluga pri karti je izredno bogastvo krajevnih slovenskih imen, približno polovica imen ima dodano tudi nemško različico. Označena so nahajališča kamnin, rudnin in montanističnih objektov, ki so pojasnjena v legendi z naslovom Fosilije in montanistični znaki. Prav tako so navedene tudi višinske kote, katerim je avtor ponekod dodal nadmorsko višino, nekatere pa označil kot triangulacijske točke. Karta je prvi slovenski stenski zemljevid, vendar z nemškim naslovom. Velja za izpopolnjeno naslednico Hacquetove litološke karte in najboljše delo slovenske kartografije pred Kozlerjem, kateremu je bila v pomoč pri izdelavi njegovega Zemljovida (Orožen 1901; Korošec 1978; Longyka 1999).

- Leta 1852 je bil natisnjen Zemljovid slovenske dežele in pokrajin Petra Kozlerja, ki nosi letnico 1853. Zemljevid prikazuje območje Koroške, Kranjske, Primorske s Kvarnerskimi otoki, del Štajerske, Prekmurja, Beneške Slovenije in Vojne krajine na Hrvaškem. Osnova zanj so bile avstrijske vojaške karte v merilu $1: 288.000$. Kozler je merilo za svojo karto zmanjšal na $1: 576.000$. Prva izdaja je bila narejena v bakrorezni tehniki, zunanji rob pa je meril približno $50 \times 55$ centimetrov. Za topografski prikaz ozemlja je uporabljena Lehmannova tehnika črtkanja in senčenja reliefa, ki je v tistem času veljala za sodobno. Na svojih kartah je to metodo začel nekaj let prej uporabljati dunajski kartografski oddelek vojno-geografskega inštituta. Zemljevid je bogat s podatki: vrisana so mesta, trgi, vasi, pošte, rudniki železa, bakra, svinca in živega srebra. Vodna in cestna mreža, železnice, rudniki, meje in kraji so označeni z vojnotopografskimi znaki v črni barvi, v kateri so natisnjena tudi krajevna in pokrajinska imena. Majhno merilo in številna imena zmanjšujejo preglednost zemljevida, zato se je avtor pri ponatisih odločil za barvanje meja in pokrajin. Je prvi zemljevid slovenskega etničnega ozemlja, kjer so imena krajev napisana v izključno slovenskem jeziku (Korošec 1978; Kranjec 1964).

Proti koncu leta 1852 je Kozler v časopisih objavil možnost predčasnega naročila zemljevida, ki bi izšel v začetku leta 1853. Konec leta 1852 se je zemljevid že tiskal, a ga je takratna oblast, ki je delovala pod vplivom Bachovega absolutizma, zaradi poudarjanja slovenstva prepovedala. Zaplenili so tiskarski plošči in vse natisnjene izvode, Kozlerja pa obsodili veleizdaje. Sporen je bil naslov zemljevida, njegove meje ter uporaba izključno slovenskega jezika. Kozler je bil v nekaj mesecih oproščen vseh obtožb, vse zaseženo pa so mu na njegovo posebno prošnjo vrnili leta 1856. Širjenje zemljevida je bilo dovoljeno šele leta 1861. Zemljevid je zaradi svojega nacionalnega naboja ter kakovostne kartografske upodobitve izšel v več ponatisih. Druga in tretja izdaja sta izšli leta 1864, četrta leta 1871, peta leta 1975, šesta leta 1978, v letih 1992 in 1995 pa sta izšli še sedma in osma izdaja (Kordiš in Škufca 1996).

Od prvega natisa dalje so se karte v podrobnostih (barve) nekoliko spreminjale, dodana pa so bila manjša obmejna območja (na Hrvaškem in Štajerskem). Najpomembnejši dodatek, ki je bil načrtovan že za leto 1853, dodan pa pri drugi izdaji leta 1864, je bil Imenik mest, tergov in krajev. Imenik je dolga leta predstavljal edini seznam krajev za celotno slovensko ozemlje. 
Slika 3: Zemljovid slovenske dežele in pokrajin. Peter Kozler, 1853. Zemljepisni muzej GIAM ZRC SAZU.

Glej angleški del prispevka.

- Leta 1856 je izšla General-Karte des Oesterreichischen Kaiserstaates mit einem grossen Theile der angrenzenden Länder (Generalna karta Avstrijskega cesarstva z delom mejnih dežel). Avtor je Josip Scheda, Ltakratni načelnik Vojnogeografskega inštituta na Dunaju. Karto sestavlja dvajset sekcij v merilu 1:576.000. Kartografsko je zelo dobra, saj je relief prikazan zelo plastično, njeno preglednost pa omejuje gostota toponimov (Marković 1993).

Kartografska dejavnost v Evropi je v drugi polovici 19. stoletja, zlasti pa ob njegovem koncu, postajala predvsem nacionalno usmerjena. Njen razvoj so pogosto vodile politika in nacionalistične težnje posameznih političnih tvorb. Obe veji moderne kartografije, tako vojna kot civilna, sta postali orodje v rokah oblasti in njihovih armad. Razvoj kartografskih tehnik in načinov prikazovanja je bil v tem času skoraj izključno v rokah vojnih geografskih in kartografskih zavodov, ki so tudi edini imeli dovolj kapitala, izšolanega in usposobljenega kadra, naprav ter dostop do podatkov. Civilni kartografski dejavnosti je bilo dovoljeno le posredovanje določene stopnje in obsega vojaških kartografskih dosežkov. Kljub temu se je postopoma tudi civilna kartografija, s pomočjo vse bolj razvejane geografske znanosti in razvojem geodetske znanosti, razvijala $v$ enakovrednega partnerja.

- V 60-ih letih 19. stoletja je bil izredno dejaven Blaž Kocen, avstrijski geograf in kartograf slovenskega rodu. Znan je predvsem po izdelavi šolskih atlasov in dveh geografskih učbenikih (Žagar 1973). Izdelal je številne stenske in ročne zemljevide, med katerimi so tudi zemljevidi slovenskih dežel: Kranjska z Istro, Štajerska, Koroška. Njegove zemljevide odlikuje nazorno prikazan relief in racionalna naselbinska mreža (Bratec Mrvar 2007).

- Med letoma 1873 in 1889 so izhajale Specialkarte der österreichisch-ungarischen Monarchie im Masse 1:75.000 (Posebne karte avstroogrske monarhije, imenovane tudi specialke). Izdelal jih je Vojnogeografski inštitut na Dunaju, služile so vojaškemu in civilnemu namenu ter bile podlaga za mnoge kasnejše topografske in tematske zemljevide. Za celotno monarhijo je bilo narejenih 715 odsekov v merilu 1:75.000. Vsak odsek ima stranice velikosti 30 minut geografske dolžine in 15 minut geografske širine. Razgibanost reliefa je prikazana s slojnicami in črtkanjem (Petrca in ostali 1974; Marković 1993).

- Leta 1879 je Carl Friederich Baur izdelal stenski zemljevid Herzogthum Krain (Vojvodstvo Kranjsko) v merilu $1: 150.000$. Zemljevid je narejen v nemškem in slovenskem jeziku ter kljub dvojnemu poimenovanju krajev dovolj pregleden. Relief je črtkan, morje in večja jezera (Bohinjsko, Blejsko, Cerkniško) so modre barve, reke so debelejše ali tanjše črne črte, nekatere nižine (na primer Ljubljanska in Celjska kotlina) so zelene barve. Ceste so prikazane z dvema vzporednima črtama, oznake krajev se ločijo glede na velikost kraja: od tankih krogcev do različno polnih krogov.

- V začetku 20. stoletja so se sodelavci in uredništvo Slovenske matice zavedli, da bi po Kozlerjevem zemljevidu slovenskega ozemlja potrebovali novejše in kakovostnejše delo s to tematiko. Delo, ki se je začelo že ob koncu 19. stoletja, se je zavleklo zaradi internih razlogov, od leta 1914 pa prekinilo zaradi prve svetovne vojne. Po vojni se je delo nadaljevalo. Leta 1921 je izšel Zemljevid slovenskega ozemlja v merilu $1: 200.000$, leto kasneje pa še Kazalo krajev na Zemljevidu slovenskega ozemlja. Osnova karte je bila ena od avstrijskih generalnih kart, njena značilnost pa je velika gostota krajevnih imen in posledično slabša preglednost (Kranjec 1964).

\section{Sklep}

V članku je navedenih več deset zemljevidov, ki delno ali v celoti prikazujejo ozemlje današnje Slovenije. Starejši zemljevidi prikazujejo slovensko ozemlje kot del širšega območja, kar je posledica razmeroma majhne politične in družbene veljave slovenskega naroda v preteklem zgodovinskem obdobju.

Zemljevidi, ki so nastajali v 17., zlasti pa od 18. stoletja dalje, v večji meri prikazujejo večji ali manjši del območja Slovenije in njene okolice. Ta način upodabljanja slovenskega prostora sovpada $\mathrm{z}$ razvojem kartografske stroke in nacionalne zavesti pri nas, ki je vsaj v začetnem obdobju temeljila na delu domačih in tujih posameznikov.

Opisi kartografskih del so nanizani kronološko glede na leto nastanka zemljevidov oziroma njegove objave. Opisi so bili izdelani na podlagi obsežne literature. Nekateri podatki o istem zemljevidu se v lite- 
raturi razlikujejo (leto nastanka, prva omemba posameznega podatka, merilo in velikost zemljevida, imena avtorjev, naslovi zemljevidov). $\mathrm{V}$ takšnih primerih smo se zanašali na novejšo literaturo, po možnosti pa na lastno preučevanje originalov. Kjer so bila kartografska dela težje dostopna oziroma nedostopna, smo se oprli izključno na literaturo.

Seznam kartografskih del, ki prikazujejo ozemlje današnje Republike Slovenije, pokaže in dokaže narodovo željo po doseganju koraka z ostalimi narodi. Gre celo za način, kako s kartografsko stroko izražati željo po enotnosti in samoohranitvi. Temu v prid govori današnja zelo dobro razvita kartografska stroka z vsemi svojimi deli in zastavljenimi načrti.

\section{Literatura}

Glej angleški del prispevka. 